\title{
Kinetics of $\mathrm{CD}^{+}$and $\mathrm{CD} 8^{+}$Memory T-Cell Responses during Hepatitis C Virus Rechallenge of Previously Recovered Chimpanzees
}

\author{
Michelina Nascimbeni, ${ }^{1}$ Eishiro Mizukoshi, ${ }^{1} \dagger$ Markus Bosmann, ${ }^{1}$ Marian E. Major, ${ }^{2}$ \\ Kathleen Mihalik, ${ }^{2}$ Charles M. Rice, ${ }^{3}$ Stephen M. Feinstone, ${ }^{2}$ \\ and Barbara Rehermann ${ }^{1 *}$ \\ Liver Diseases Section, National Institute of Diabetes and Digestive and Kidney Diseases, National Institutes of \\ Health, ${ }^{1}$ and Laboratory of Hepatitis Research, Center for Biologics Evaluation and Research, Food and \\ Drug Administration, ${ }^{2}$ Bethesda, Maryland 20892, and Center for the Study of Hepatitis C, \\ The Rockefeller University, New York, New York $10021^{3}$
}

Received 2 October 2002/Accepted 22 January 2003

\begin{abstract}
The immunological correlates of hepatitis C virus (HCV)-specific immunity are not well understood. Antibodies to HCV structural proteins do not appear to play a key role in clearance of the virus and do not persist after recovery. Here, we studied the kinetics of the cellular immune responses of three HCV-recovered chimpanzees during rechallenge with increasing doses of homologous HCV. Although HCV envelope antibodies remained undetectable throughout the rechallenge, all animals mounted rapid $\mathrm{HCV}$-specific $\mathrm{T}$-cell responses. The pattern of the cellular immune response in blood and liver correlated with the virological outcome. The animal that most rapidly cleared circulating HCV as determined by nested reverse transcription-PCR (RTPCR) displayed the most vigorous and sustained response of gamma interferon (IFN- $\gamma$ )-producing and proliferating CD4 ${ }^{+} \mathrm{T}$ cells in the blood. Vigorous $\mathrm{CD}^{+}$T-cell proliferation during viremia was followed by an increased frequency and a phenotypic and functional change of the tetramer ${ }^{+} \mathrm{CDB}^{+} \mathrm{T}$-cell population. The second animal cleared $\mathrm{HCV}$ initially with strong peripheral and intrahepatic $\mathrm{CD}^{+}{ }^{+} \mathrm{T}_{\text {-cell }}$ responses but experienced low-level HCV recrudescence 12 weeks later, when $\mathrm{HCV}$-specific $\mathrm{T}$ cells became undetectable. The third animal maintained minute amounts of circulating HCV, detectable only by nested RT-PCR, in the face of a weak IFN- $\gamma^{+}$T-cell response. Collectively, the results suggest protective rather than sterilizing immunity after recovery from hepatitis $\mathrm{C}$. The rate of $\mathrm{HCV}$ clearance following reexposure depends on the cellular immune response, the quality and quantity of which may vary among chimpanzees that recovered from $\mathrm{HCV}$ infection.
\end{abstract}

Hepatitis $\mathrm{C}$ virus (HCV) infection is the leading cause of chronic viral hepatitis, liver disease, and hepatocellular carcinoma. Although it is reported that 54 to $86 \%$ of HCV infections are not cleared (50), recent clinical studies suggest that acquired immunity against HCV might exist in frequently exposed subjects (36). HCV-specific antibodies do not prevent reinfection $(17,30,44)$ and are not maintained in many persons that have recovered from HCV infection (53). It has therefore been proposed that this acquired immunity is mediated by $\mathrm{T}$ cells. Indeed, $\mathrm{HCV}$-specific $\mathrm{T}$-cell responses are detectable in the blood of patients $(4,11,18,22,32,37,55)$ and in the livers of chimpanzees $(10,15)$ with self-limited courses of acute hepatitis $\mathrm{C}$ and can be maintained for decades after recovery $(7,53)$. These $\mathrm{CD}^{+}$and $\mathrm{CD}^{+}{ }^{+} \mathrm{T}$ cells target epitopes in all viral proteins and produce predominantly type 1 cytokines such as gamma interferon (IFN- $\gamma$ ), interleukin-2 (IL$2)$, and tumor necrosis factor alpha $(32,40,57)$.

It is unclear, however, how HCV-specific memory $\mathrm{T}$ cells

\footnotetext{
* Corresponding author. Mailing address: Liver Diseases Section, NIDDK, National Institutes of Health, 10 Center Dr., Room 9B16, Bethesda, MD 20892. Phone: (301) 402-7144. Fax: (301) 402-0491. E-mail: Rehermann@nih.gov.

$\dagger$ Present address: First Department of Internal Medicine, Kanazawa University School of Medicine, Kanazawa, Ishikawa 920-8641, Japan.
}

react upon reexposure to the virus. Specifically, whether only $\mathrm{HCV}$-specific CD4 ${ }^{+} \mathrm{T}$ cells (7) or $\mathrm{CD}^{+}{ }^{+}$and $\mathrm{CD}^{+} \mathrm{T}$ cells (7) persist after recovery from hepatitis $\mathrm{C}$ is controversial, and similar research questions about the differential regulation of $\mathrm{CD}^{+}$and $\mathrm{CD}^{+}$memory $\mathrm{T}$ cells are also studied for other viral infections (58). The situation regarding the functionality of HCV-specific T cells is even more complex. So far, transient proliferation is the only effector function for $\mathrm{CD}^{+}{ }^{+} \mathrm{T}$ cells that has been described in a recent study on HCV rechallenge of chimpanzees that had recovered from HCV infection (3). $\mathrm{CD}^{+} \mathrm{T}$ cells have not been prospectively studied during $\mathrm{HCV}$ rechallenge. These issues are addressed in the present study.

Analysis of the peripheral blood and intrahepatic cellular immune responses during $\mathrm{HCV}$ rechallenge requires an animal model, and the only animal susceptible to HCV infection is the chimpanzee. Due to the limited availability of chimpanzees, many published hepatitis B virus (HBV) and HCV studies only include one $(42,61)$ or two chimpanzees $(25,34,64)$. Nevertheless, the development of full-length HCV cDNA clones and sequence-matched antigens and the identification of immunogenic $\mathrm{HCV}$ peptides that are recognized in the context of chimpanzee (Pan troglodytes [Patr]) alleles have made this a valuable animal model to analyze the cellular immune response in relation to the clinical and virological courses of $\mathrm{HCV}$ reinfection. 
In this study, we rechallenged three chimpanzees that had previously recovered from $\mathrm{HCV}$ infection with increasing doses of homologous HCV. We $(35)$ and others $(3,62)$ previously reported a comparison of the clinical and virological courses of reinfections to those of primary infections. All rechallenged animals cleared HCV to below the detection level of real-time reverse transcription-PCR (RT-PCR) more rapidly and displayed significantly less liver disease than during primary infection. In the present report, we have prospectively analyzed $\mathrm{HCV}$-specific T-cell responses in the blood and livers of these animals during rechallenge. Although all rechallenged chimpanzees rapidly controlled HCV to levels below 400 copies/ml, distinct virological differences were detected at the RTPCR level and correlated with the cellular immune response. Vigorous HCV-specific T-cell responses were associated with rapid HCV control in chimpanzee Ch4X0186, whereas weak proliferation of $\mathrm{HCV}$-specific $\mathrm{T}$ cells was associated with persistence of trace amounts of $\mathrm{HCV}$ in Ch1605, and loss of proliferative $\mathrm{HCV}$-specific $\mathrm{T}$-cell responses was associated with HCV recrudescence in Ch1552. Collectively, the data suggest that the degree of $\mathrm{HCV}$-specific cellular immunity correlates with the outcome of rechallenge.

\section{MATERIALS AND METHODS}

Chimpanzees. Chimpanzees were housed at Southwest Foundation for Biomedical Research (San Antonio, Tex.) and the Food and Drug Administration (Bethesda, Md.) under protocols approved by the Institutions' Animal Care and Use Committees and the Public Health Service Interagency Model Committee. Ch4X0186 was 18 years old, Ch1552 was 6 years old, and Ch1605 was 5 years old at the start of this rechallenge study. Ch4X0186 had been vaccinated against HBV in 1983 and challenged with HBV in 1987; none of the animals had been infected with human immunodeficiency virus. The Patr class I haplotypes were Patr-A*0401 Patr-B*0101 Patr-B*1601 for Ch4X0186, Patr-A*0701 Patr-A*0901 Patr-B*0101 Patr-B*1301 for Ch1552, and Patr-A*0501 Patr-B*0501 Patr-B*1301 for Ch1605 (38)

As regards the primary HCV infection (see Table 1), Ch4X0186 had been intravenously inoculated in 1993, i.e., 5.2 years prior to this rechallenge study, with a passage of the well-characterized $\mathrm{H} 77$ serum, obtained from an HCVinfected patient (genotype 1a) and had developed acute, self-limited hepatitis C (R. Lanford, personal communication). Ch1552 had been intrahepatically inoculated with RNA transcripts from nonconsensus HCV cDNA clones and from cDNA clones with lethal mutations but had not developed any productive infection (26). In 1998, i.e., 1.2 years prior to this rechallenge study, Ch1552 was intrahepatically inoculated with in vitro-transcribed clonal HCV RNA (genotype 1a) generated from the $\mathrm{H} 77$ sequence and had developed acute, self-limited hepatitis $\mathrm{C}$ (26). Ch1605 had been intravenously inoculated with increasing doses (0.032, 0.32, and $3.250 \%$ chimpanzee infectious doses [CID $\left.{ }_{50}\right]$, respectively) of chimpanzee plasma that contained clonal HCV (genotype 1a) but no detectable antibodies and had developed acute, self-limited hepatitis C in 1999, i.e., 1.8 years prior to this rechallenge study. All animals had recovered from the primary $\mathrm{HCV}$ infection and had tested negative for HCV RNA by RT-PCR in serum and liver prior to and at the time of the rechallenge.

Rechallenge inocula. The homologous HCV 1a rechallenge inoculum was obtained from previously infected chimpanzee Ch1536 prior to development of anti-HCV antibodies (25). It consisted of a single, detectable HCV sequence (p90), was free of detectable HCV antibodies, and had a PCR titer of $4 \times 10^{5}$ copies $/ \mathrm{ml}$ and an infectious titer of $10^{4.5} \mathrm{CID}_{50} / \mathrm{ml}$. The heterologous HCV $1 \mathrm{~b}$ inoculum used to rechallenge $\mathrm{Ch} 4 \mathrm{X} 0186$ after recovery from the $\mathrm{HCV}$ 1a rechallenge was a kind gift from Jens Bukh and Robert Purcell, National Institutes of Health (NIH). It consisted of a plasma pool of strain HC-J4 (41) and had a PCR titer of $10^{4}$ to $10^{5}$ genome equivalents $/ \mathrm{ml}$ and an infectivity titer of approximately $10^{3} \mathrm{CID}_{50} / \mathrm{ml}$ (65). All rechallenge inocula were given intravenously.

Analysis of HCV-specific antibodies. Antibodies against HCV antigens (c22, HCVcore10-53; c33c, HCV-NS3 1192-1457; 5-1-1, HCV-NS4 1694-1735; c100, HCV-NS4 1920-1935; NS5, HCV-NS 52054-2995) were detected by strip immunoblot assay (Chiron*RIBA*HCV3.0 SIA; Chiron Corporation, Emeryville, Calif.). Briefly, $\mathrm{HCV}$ antigens were immobilized as individual bands on test strips, incubated with chimpanzee sera, washed, incubated with peroxidase-labeled goat anti-human immunoglobulin $\mathrm{G}$ ( $\mathrm{IgG}$ ) conjugate, and subjected to colorimetric enzyme detection using hydrogen peroxide and 4-chloro-1-naphthol. The intensity of each HCV band was compared to the intensity of the human IgG internal control band according to the manufacturer's instructions. The assay scored negative if no HCV band was observed, indeterminate if a single HCV band with an intensity equal to or greater than that of the $\mathrm{IgG}$ control band was detected, and positive if at least two HCV bands with intensities equal to or greater than that of the IgG control band were detected.

In addition, enzyme-linked immunosorbent assays (ELISAs) were performed with the Ortho HCV, version 3.0, ELISA system (Ortho-Chemical Diagnostics, Rochester, N.Y.) and with recombinant E1/E2 and NS3 proteins, whose sequences were the same as those of proteins of the rechallenge virus, as previously described (34). Sera were tested undiluted and in 1:10 and 1:80 dilutions, respectively.

Peptides, proteins, and antibodies. $\mathrm{CD}^{+} \mathrm{T}$-cell responses were analyzed with $\mathrm{HCV}$ epitope peptides (Research Genetics, Huntsville, Ala.) that we had previously shown to be recognized by the chimpanzees included in this study (38). The sequences of all peptides matched the sequence of the rechallenge virus. Peptides 1 (Core $\left.{ }_{35-44}\right), 4\left(\right.$ Core $\left._{131-140}\right), 5\left(\right.$ Core $\left._{167-176}\right), 10\left(\mathrm{NS3}_{1073-1081}\right), 13$ (NS3 $\left.{ }_{1406-1415}\right), 14$ (NS3 $\left.1444-1452\right), 16\left(\mathrm{NS}_{18 \mathrm{~B}_{1807-1816}}\right)$, and 18 (NS5B $\left.\mathrm{B}_{2727-2735}\right)$ were used to study Patr-B*0101 ${ }^{+}$chimpanzees Ch4X0186 and Ch1552; peptides

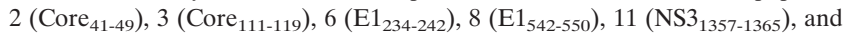
12 (NS3 $\left.{ }_{1379-1386}\right)$ were used to study Patr-B*1301 ${ }^{+}$chimpanzees Ch1552 and Ch1605; peptides $7\left(\mathrm{E}_{306-315}\right)$ and $9\left(\mathrm{E}_{588-596}\right)$ were used to study Patr-A*04 chimpanzee Ch4X0186; peptides 15 (NS4 $1765-1773), 17$ (NS5B $\left.{ }_{2639-2646}\right)$, and 19

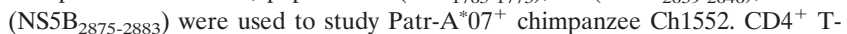
cell responses were analyzed with recombinant HCV core, NS3, helicase, NS4, NS5A, and NS5B proteins (genotype 1b; Mikrogen) (53) and Sindbis virus-expressed recombinant HCV E1/E2 (sequence of the rechallenge inoculum) (34).

The following antibodies were used for flow cytometry: anti-CD4-fluorescein isothiocyanate (FITC), anti-CD8-PerCP, anti-CD4-PerCP, and anti-CD19PerCP (Becton Dickinson, San Jose, Calif.); anti-CD13-FITC, anti-CD19-FITC, and anti-CD45RO-allophycocyanin (APC) (Caltag Laboratories, Burlingame, Calif.); purified anti-CCR7 and anti-CD38-APC (BD Pharmingen, San Diego, Calif.); goat anti-mouse IgM $\mu$ chain-FITC (Jackson ImmunoResearch Laboratories, Baltimore, Pa.); and IgG1 and IgG2a isotype control antibodies.

Quantitative and qualitative detection of HCV RNA. Quantitative real-time RT-PCR (detection limit, 400 RNA copies $/ \mathrm{ml}$ ) and qualitative nested RT-PCR (detection limit, 40 RNA copies/ml) were performed with total RNA extracted from $100 \mu \mathrm{l}$ of serum or from $1 \mathrm{~mm}^{3}$ of the week 13 and week 15 snap-frozen liver biopsy samples from Ch4X0186 as previously described (45).

Synthesis of Patr tetramers. Isolation of total RNA from Epstein-Barr virustransformed B-cell lines (38) or from peripheral blood mononuclear cells (PBMC) and first-strand cDNA synthesis were performed as previously described (14). PCR-amplified Patr class I cDNA was cloned into the pGEM11Zf $(+)$ vector (Promega, Madison, Wis.). At least five molecular clones per Patr allele of each chimpanzee were sequenced by using the T7 forward primer and primers $3 \mathrm{~S}, 3 \mathrm{~N}, 4 \mathrm{~S}$, and $4 \mathrm{~N}$ (14) and analyzed with DNASIS software (Hitachi Software Engineering Co., Ltd.). Error-free Patr inserts were subcloned into pCMV-Script (Stratagene, La Jolla, Calif.), and human $\beta_{2}$-microglobulin was expressed from the plasmid pHN1-2m as described previously (20). Folding, purification, biotinylation, and tetramer production of $\mathrm{HCV}$ peptide major histocompatibility complex class I complexes were performed at the National Institute of Allergy and Infectious Diseases Tetramer Facility of the NIH AIDS Research and Reference Reagent Program according to methods previously described (1).

Tetramer staining of T-cell lines and PBMC. The specificity of new Patr tetramers was confirmed with cytotoxic chimpanzee T-cell lines (38) specific either for the peptide of interest or for an irrelevant peptide. PBMC were stained with either (i) tetramer-phycoerythrin (PE; 1:100), CD4-FITC, CD14-FITC, CD19-FITC, CD8-PerCP, and CD38-APC or (ii) tetramer-PE (1:100), CD4PerCP, CD19-PerCP, CD45RO-APC, and purified CCR7 for $30 \mathrm{~min}$ at room temperature. An anti-IgM-FITC secondary antibody was used after staining with CCR7. Up to $1.3 \times 10^{6}$ events in the lymphogate were acquired on a FACSCalibur (Becton Dickinson) by using Cellquest (Becton Dickinson) and FlowJo (San Carlos, Calif.) software for analysis. Nonspecific background staining was determined by staining PBMC from three to nine Patr-matched HCV-naive chimpanzees and from four to six Patr-mismatched HCV-infected chimpanzees and yielded the following background staining for conditions (i) and (ii), respectively: 0.009 and $0.0052 \%$ for the Patr-A*04/peptide 7 tetramer; 0.0033 and $0.009 \%$ for the Patr-A*1301/peptide 8 tetramer, 0.0065 and $0.012 \%$ for the Patr-B*1301/peptide 11 tetramer, 0.015 and $0.012 \%$ for the Patr-B* $1301 /$ peptide 
TABLE 1. Clinical and virological course of primary HCV infection and rechallenge

\begin{tabular}{|c|c|c|c|c|c|c|}
\hline \multirow[b]{2}{*}{ Type of infection } & \multirow[b]{2}{*}{ Chimpanzee } & \multirow{2}{*}{$\begin{array}{l}\text { Route of } \\
\text { inoculation }^{c}\end{array}$} & \multicolumn{2}{|c|}{ ALT } & \multicolumn{2}{|c|}{ Viremia } \\
\hline & & & $\begin{array}{c}\text { Maximum activity } \\
\text { (U/liter) }\end{array}$ & $\begin{array}{c}\text { Duration (wks) } \\
\text { of elevation }^{a}\end{array}$ & $\begin{array}{l}\text { Maximum titer } \\
\text { (RNA copies/ml) }\end{array}$ & $\begin{array}{c}\text { Duration (wks) } \\
\left(>400 \text { copies } / \mathrm{ml}^{a}\right)\end{array}$ \\
\hline \multirow[t]{3}{*}{ Primary HCV 1a inoculation } & $\mathrm{Ch} 4 \mathrm{X} 0186$ & i.v. & 160 & $>8$ & $2 \times 10^{5}$ & $8+1^{d}$ \\
\hline & Ch1552 & i.h. & 249 & $10+1$ & $1 \times 10^{7}$ & $15+1$ \\
\hline & Ch1605 & i.v. & 176 & $10+1$ & $1 \times 10^{6}$ & $11+1$ \\
\hline \multirow[t]{3}{*}{ Rechallenge with homologous HCV 1a } & $\mathrm{Ch} 4 \mathrm{X} 0186$ & i.v. & 53 & $2+1$ & $<4 \times 10^{2}$ & 0 \\
\hline & Ch1552 & i.v. & 31 & $1+1$ & $4 \times 10^{3}$ & $1+1$ \\
\hline & Ch1605 & i.v. & 70 & $3+1$ & $5 \times 10^{4}$ & $1+1$ \\
\hline Rechallenge with heterologous HCV $1 \mathrm{~b}$ & Ch4X0186 & i.v. & 86 & $1+1$ & $<4 \times 10^{2}$ & 0 \\
\hline
\end{tabular}

${ }^{a}$ Serum samples were tested at weekly intervals; the durations of ALT elevation and viremia are therefore indicated with 1-week variance.

${ }^{b}$ Quantitative real-time RT-PCR (sensitivity, 400 RNA copies $/ \mathrm{ml}$ ).

${ }^{c}$ i.v., intravenous HCV infection; i.h., intrahepatic transfection with in vitro-transcribed HCV RNA.

${ }^{d}$ Robert Lanford, personal communication.

12 tetramer, and 0.0015 and $0.004 \%$ for the Patr-B*0101/peptide 14 tetramer. For the analysis of tetramer ${ }^{+}$cells from Patr-matched HCV-infected chimpanzees (see the phenotypic analysis of tetramer ${ }^{+}$cells in Fig. 2 and Fig. 4) we considered only samples with at least 50 events in the tetramer gate as positive.

ELISPOT assay. IFN- $\gamma$ enzyme-linked immunospot (ELISPOT) assays were performed as previously described (53) with duplicate cultures of $1.2 \times 10^{5}$ cryopreserved and thawed PBMC, $10 \mu \mathrm{g}$ of $\mathrm{HCV}$ peptide/ml, $1 \mu \mathrm{g}$ of $\mathrm{HCV}$ protein/ml, or $1 \mu \mathrm{g}$ of phytohemagglutinin (PHA) (Murex Biotech Limited, Dartford, England)/ml. The number of specific spots (spots in the presence of antigen minus spots in the absence of antigen) was determined with a KS ELISPOT reader (Carl Zeiss Inc., New York, N.Y.). The cutoff for a significant response was 11 spots/120,000 PBMC for each HCV protein and 12 specific spots/120,000 PBMC for each peptide, equivalent to the means plus 2 standard deviations of protein- and peptide-specific responses of naive chimpanzees.

Proliferation assay. Proliferation assays were performed with PBMC that had been cryopreserved using the Biocool machine (FTS Systems Inc., Stone Ridge, N.Y.) and subsequently thawed and with liver-derived T-cell lines. Triplicate cultures of 50,000 or 200,000 PBMC were stimulated with $1 \mu \mathrm{g}$ of HCV proteins/ $\mathrm{ml}$, the buffer control, or $1 \mu \mathrm{g}$ of $\mathrm{PHA} / \mathrm{ml}$ as previously described (53). Liverderived T-cell lines were tested 3 weeks after the last restimulation in the presence of 100,000 irradiated $(3,000 \mathrm{rad})$ autologous PBMC. $\left[{ }^{3} \mathrm{H}\right]$ thymidine (ICN, Costa Mesa, Calif.) was added on day 3 (T-cell lines) or day 5 (PBMC) for $16 \mathrm{~h}$. Results were expressed as stimulation index (counts per minute in the presence of antigen/counts per minute in the absence of antigen). The cutoff was calculated for each protein based on proliferation assays with PBMC from five naive chimpanzees, yielding a cumulative cutoff of 10.9 (core, 1.8; NS3, 1.7; helicase, 1.6; NS4, 2.0; NS5A, 1.7; NS5B, 2.1).

Analysis of lymphocytes derived from liver biopsy samples. Liver biopsy samples for direct ex vivo analysis by flow cytometry from Ch1552 and Ch1605 were available. Biopsy samples were measured and weighed in sterile petri dishes. Lymphocytes were isolated by mechanical homogenization, counted, and stained with anti-CD3 and anti-CD56. The numbers of $\mathrm{CD}^{+}{ }^{+} \mathrm{CD}_{5}{ }^{-}$conventional T cells, $\mathrm{CD}^{-}{ }^{-} \mathrm{CD} 56^{+} \mathrm{NK}$ cells, and $\mathrm{CD} 3^{+} \mathrm{CD} 56^{+}$lymphocytes were determined by flow cytometry. The $\mathrm{CD}^{+} \mathrm{CD}^{+} 6^{+}$population consisted of innate lymphocytes with natural killer cell markers and activation and memory markers and is predominantly present in peripheral tissues $(12,13)$.

Liver biopsy samples for isolation and cloning of lymphocytes were available from Ch4X0186 at weeks 11 and 15 and from Ch1552 at weeks 6, 12, and 14. In addition, lymphocytes were cloned with 100,000 gamma-irradiated (7,000 rad) PBMC, $0.01 \mu \mathrm{g}$ of anti-CD3/ml, and $100 \mathrm{U}$ of IL-2/ml as previously described (28) and tested for HCV-specific proliferation. Cytotoxicity was assessed in ${ }^{51} \mathrm{Cr}$ release assays (53) using as target cells autologous PHA-stimulated lymphoblasts that had been infected with $\mathrm{T} 7$ vaccinia virus and a recombinant vaccinia virus expressing the full-length $\mathrm{HCV}$ protein or, as a control, with the $\mathrm{T} 7$ vaccinia virus alone at a multiplicity of infection of 10 .

\section{RESULTS}

Cross-sectional analysis of the clinical and virological courses of primary and rechallenge $\mathrm{HCV}$ infection. The immunological analysis was performed on a group of chimpan- zees that had originally been part of virological studies to assess the infectivity of in vitro-transcribed full-length $\mathrm{HCV}$ RNA and the titer of virus derived from such productively infected animals $(26,35)$. The detailed course and clinical outcome of the rechallenge of these animals have previously been reported (35) and are summarized in Table 1.

In the primary infection, all animals developed peak viral titers between $2 \times 10^{5}$ and $1 \times 10^{7} \mathrm{HCV}$ RNA copies per ml of serum and evidence of liver injury, with peak serum alanine aminotransferase (ALT) levels between 160 and 249 U/liter (Table 1). In all animals, serum ALT levels remained elevated for at least 8 weeks. HCV RNA remained above the cutoff of real-time PCR for 8 to 15 weeks. All animals recovered from $\mathrm{HCV}$ infection, and serum and liver biopsy samples tested repeatedly negative for HCV RNA by nested RT-PCR.

Ch4X0186, Ch1552, and Ch1605 were rechallenged 5.2, 1.2, and 1.8 years after the primary infection, respectively, with homologous HCV 1a. Ch4X0186 and Ch1552 received increasing doses of the rechallenge inoculum at 4-week intervals (see Fig. 1A and 3A), whereas Ch1605 received a single injection of $100 \mathrm{CID}_{50}$. All three animals displayed significantly lower serum ALT levels and HCV RNA titers during their rechallenge than during their primary infections and resolved the rechallenge viremia more rapidly (Table 1 ). The same outcome was observed when Ch4X0186 was subsequently rechallenged with $100 \mathrm{CID}_{50}$ of heterologous HCV 1b (Table 1).

To evaluate the possibility that several low-dose exposures could have attenuated the nature of the subsequent high-dose exposure, we performed two additional comparisons. First, during primary infection, Ch1605 received increasing doses of virus and displayed the same clinical and virological courses as Ch4X0186 and Ch1552 (35) and six additional chimpanzees (M. Major et al., unpublished data) which each received a single inoculation of the identical virus. Second, during rechallenge Ch4X0186 and Ch1552 received increasing doses of virus and displayed the same clinical and virological courses as Ch1605, which received a single rechallenge inoculation.

Prospective analysis of the peripheral blood immune response during rechallenge. To evaluate the components and kinetics of the $\mathrm{T}$-cell response in relation to the virological course of HCV reinfection, the immune responses of the three rechallenged chimpanzees were then studied in detail in a 


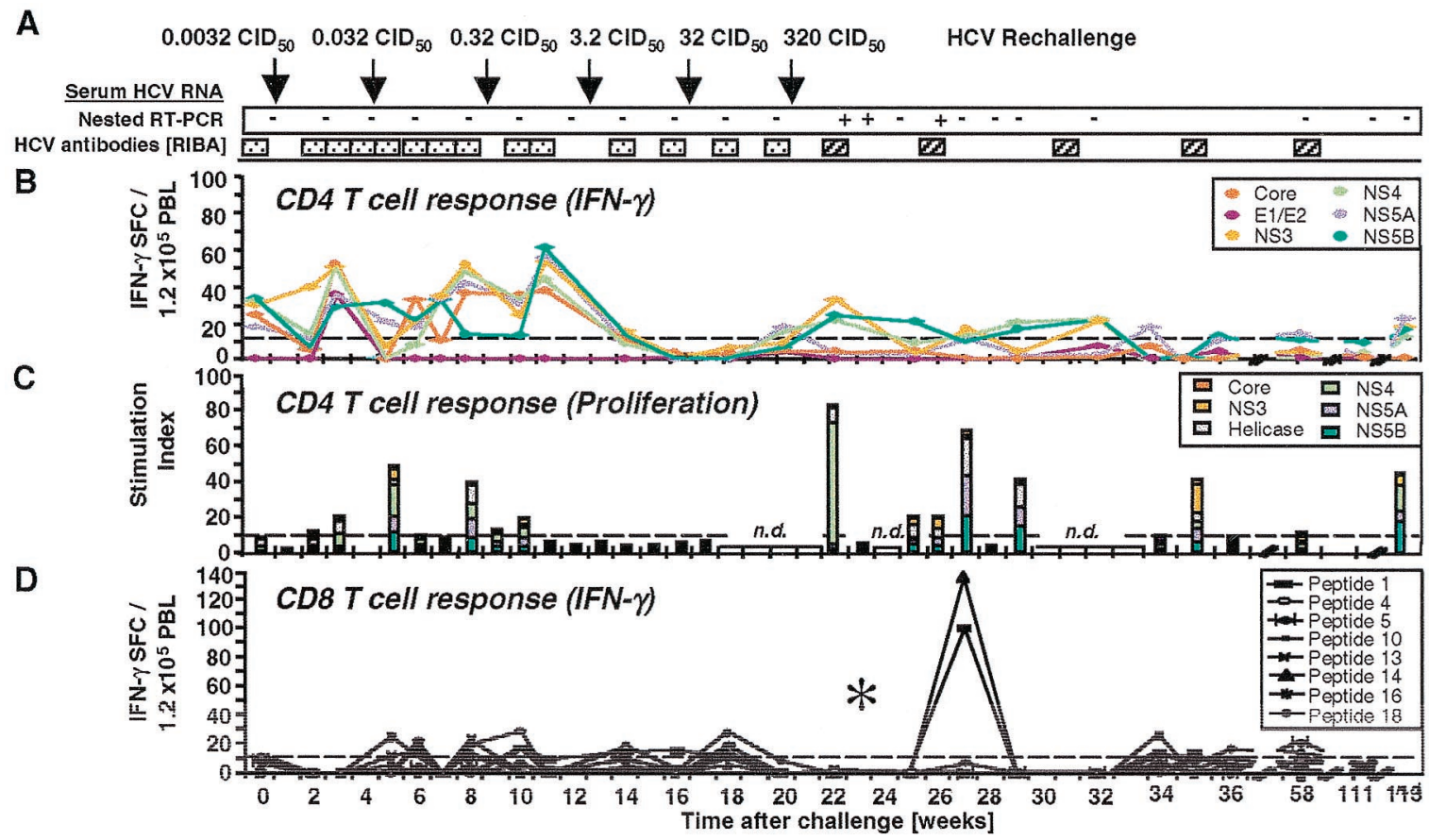

FIG. 1. HCV-specific $\mathrm{CD}^{+}$and $\mathrm{CD}^{+}$T-cell responses of $\mathrm{Ch} 4 \mathrm{X} 0186$ during $\mathrm{HCV}$ rechallenge. (A) Arrows, time points of intravenous inoculation. All sera tested negative by real-time PCR (detection limit, $400 \mathrm{HCV}$ RNA copies/ml). Presence $(+)$ or absence $(-)$ of virus below the detection limit of real-time PCR was assessed by nested RT-PCR. HCV antibody RIBA scores: indeterminate (圈), a single HCV band with an intensity equal to or greater than that of the $\mathrm{IgG}$ control band was detected; positive (逐), at least two HCV bands with intensities equal to or greater than that of the IgG control band were detected. Only antibodies against HCV NS3 and NS4B were detected; all other antigens, including the E1/E2 glycoproteins, tested negative. (B) Frequency of HCV-specific T cells that produce IFN- $\gamma$ in response to HCV proteins (ELISPOT analysis). Responses are indicated as specific spot-forming cells (SFC) per $1.2 \times 10^{5}$ peripheral blood lymphocytes (PBL) (number of SFC in the presence of antigen - number of SFC in the absence of antigen). (C) Proliferative T-cell response to HCV proteins. The stimulation index represents proliferation in the presence of antigen divided by proliferation in the absence of antigen. Dotted line, cutoff of positivity; n.d., not done. (D) Frequency of $\mathrm{HCV}$-specific $\mathrm{CD}^{+} \mathrm{T}$ cells that produce IFN- $\gamma$ in response to eight HCV peptide epitopes (ELISPOT analysis). HCV peptides were selected according to the animal's Patr haplotype (38). *, time point (week 23) with the highest number of tetramer ${ }^{+} \mathrm{T}$ cells (see Fig. 2C).

prospective manner. The following paragraphs describe for each chimpanzee individually (i) humoral immune responses, studied by strip immunoblot assays (RIBAs) and ELISAs; (ii) peripheral blood $\mathrm{CD}^{+}{ }^{+} \mathrm{T}$-cell responses studied for $\mathrm{HCV}$ specific proliferation, IFN- $\gamma$, and IL-5 production; and (iii) peripheral blood $\mathrm{CD}^{+} \mathrm{T}$-cell responses quantitated and phenotyped with HCV peptide major histocompatibility complex tetramers and assessed for IFN- $\gamma$ production.

Peripheral blood immune response of $\mathrm{Ch} 4 \mathrm{X0186}$ during rechallenge. Figure 1 shows the prospective analysis of the humoral and cellular peripheral blood immune response of Ch4X0186 during rechallenge. At the time of rechallenge (week 0; Fig. 1), Ch4X0186 did not display any antibodies to $\mathrm{HCV}$ envelope glycoproteins. Antibodies to HCV NS3 were present, as indicated by a single positive band in the RIBA (not shown), resulting in an overall RIBA score of "indeterminate" (Fig. 1A). Whereas the undiluted week 0 serum tested positive in the Ortho version 3.0 ELISA, a 1:10 dilution of it tested negative, indicating a low titer of $\mathrm{HCV}$-specific antibodies.

$\mathrm{CD4}^{+} \mathrm{T}$-cell response of $\mathbf{C h} 4 \mathrm{X0186}$. In contrast to the weak humoral immune response, Ch4X0186 displayed IFN- $\gamma$-producing PBMC specific for multiple structural and nonstructural $\mathrm{HCV}$ proteins at the time of rechallenge (week 0; Fig. 1B). Separate analysis of $\mathrm{CD}^{+}$and $\mathrm{CD}^{+} \mathrm{T}$ cells identified $\mathrm{CD}^{+} \mathrm{T}$ cells as the responding population (not shown). More- over, changes in the cellular immune response were even observed in response to very-low-dose inocula. First, after each inoculation with $0.0032,0.032$, and $0.32 \mathrm{CID}_{50}$, respectively, the number of $\mathrm{HCV}$-specific, IFN- $\gamma$-producing PBMC decreased and then slowly recovered and even increased during the following weeks (weeks 3, 8, and 11; Fig. 1B) even though $\mathrm{HCV}$ replication remained undetectable by nested RT-PCR analysis of serum and liver biopsy samples (Fig. 1A). Second, after low-dose inoculation, the vigor of the proliferative response to HCV proteins appeared to increase (weeks 5 and 8; Fig. 1C). At the same time points, there was also a slight increase in the frequency of IFN- $\gamma$-producing $\mathrm{CD}^{+} \mathrm{T}$ cells that responded to individual Patr restricted peptides (weeks 5, 6, 8, and 10; Fig. 1D). Thus, changes of the different components of the peripheral blood T-cell response were observed even in response to low-dose inocula that did not result in detectable viremia. In contrast, no significant changes of $\mathrm{HCV}$ specific antibodies in response to low-dose inocula were observed in RIBAs (Fig. 1A) and ELISAs (not shown).

Next, chimpanzee Ch4X0186 was inoculated with 3.2 CID $_{50}$ (week 12; Fig. 1A). Although this dose typically infects naive chimpanzees, Ch4X0186 remained negative for HCV RNA by RT-PCR. Interestingly, the number of circulating, IFN- $\gamma$-producing $\mathrm{CD}^{+}{ }^{+} \mathrm{T}$ cells decreased significantly, and these $\mathrm{T}$ cells were completely undetectable at weeks 16 and 18 . This effect 
was maintained during subsequent inoculation of a 10 -foldhigher dose, $32 \mathrm{CID}_{50}$, despite the fact that inoculation of 32 $\mathrm{CID}_{50}$ did not result in detectable viremia or in any changes in the humoral immune response. To determine the underlying mechanisms for this observation, we examined three possibilities. First, to analyze whether a Th1-to-Th2 switch could explain the decreased IFN- $\gamma$ production (57), we performed IL-5 ELISPOT analysis. However, even in the absence of any detectable IFN- $\gamma$ production, a switch to IL-5 production was not observed (not shown).

Because the decrease of IFN- $\gamma$ production was accompanied by loss of detectable T-cell proliferation (weeks 12 to 18; Fig. 1C), it was possible that HCV-specific T cells had left the circulation during this period. To examine whether $\mathrm{T}$ cells accumulated in the liver in response to minute amounts of replicating virus, liver-infiltrating lymphocytes were cloned in an antigen-nonspecific manner from the week 11 and week 15 biopsy samples and tested for HCV specificity in proliferation assays using $\mathrm{HCV}$ proteins and in cytotoxicity assays using autologous PHA-stimulated blasts that expressed a vaccinia virus-encoded full-length $\mathrm{HCV}$ polyprotein with the same amino acid sequence as the rechallenge virus. For the week 11 biopsy sample, obtained prior to inoculation of $3.2 \mathrm{CID}_{50}$ when $\mathrm{HCV}$-specific, IFN- $\gamma$-producing T cells were still detectable in the blood, 3 of 145 (2.1\%) intrahepatic T-cell lines tested HCV specific in proliferation assays. For the week 15 biopsy sample, obtained when HCV-specific T cells were undetectable in the blood, 2 of $48(4.2 \%)$ T-cell lines were HCV specific. Thus, the number of proliferating, $\mathrm{HCV}$-specific $\mathrm{T}$ cells increased only slightly in the liver when the number in the blood decreased. This result is consistent with the fact that HCV RNA was not detectable by RT-PCR in the week 13 and 15 liver biopsy samples.

Finally, we considered the possibility that circulating $\mathrm{T}$ cells might have left the circulation and been transformed into proliferating T-cell clones in the regional lymph nodes, as has been found after low-dose antigen exposure in other infections (51). Interestingly, the temporary absence of circulating HCV-specific $\mathrm{T}$ cells was followed by a vigorous proliferative burst of $\mathrm{HCV}$-specific $\mathrm{CD}^{+}{ }^{+} \mathrm{T}$ cells (stimulation index of 83; Fig. 1C) at week 22, just after $\mathrm{HCV}$ rechallenge with $320 \mathrm{CID}_{50}$, when the chimpanzee developed detectable viremia. This proliferative response also coincided with the reappearance of IFN- $\gamma$ producing cells in the blood (week 22; Fig. 1B and D). Collectively, these observations are consistent with the generation of new effector cell populations in lymphoid organs.

Within 4 weeks, HCV was cleared from the circulation, and clearance was associated with a proliferative $\mathrm{T}$-cell response specific for HCV nonstructural proteins (week 27; Fig. 1C). Importantly, $\mathrm{HCV}$-specific proliferating and IFN- $\gamma$-producing $\mathrm{T}$ cells remained detectable in the peripheral blood for at least 1.5 years of follow-up and HCV RNA remained undetectable by RT-PCR in serum and liver biopsy samples. Following this T-helper-cell response, RIBA turned from indeterminate to clearly positive (week 22; Fig. 1A), detecting antibodies against HCV nonstructural proteins NS3 and NS4B. Antibodies against HCV envelope glycoproteins, however, remained undetectable during the whole prospective follow-up. This type of response was repeated during rechallenge with heterologous HCV 1b (not shown).
$\mathrm{CD8}^{+}$T-cell response of $\mathbf{C h} 4 \mathrm{X0186}$. To analyze the HCVspecific $\mathrm{CD}^{+}$T-cell response, we determined the animal's Patr class I haplotype and selected HCV epitope peptides recognized in the context of these specific Patr alleles (38). Prior to rechallenge (week 0; Fig. 1D), the IFN- $\gamma$ response of circulating peptide-specific $\mathrm{CD}^{+} \mathrm{T}$ cells was weak and below the cutoff of the ELISPOT assay (week 0; Fig. 1D). To analyze whether the weakness of the response was due to the low frequency of HCV-specific T cells, we cloned the Patr alleles of this animal and generated Patr tetramers. Figure 2A demonstrates the specificity of Patr B0101 and Patr A04 tetramers for specific and irrelevant $\mathrm{T}$-cell lines. Figure $2 \mathrm{~B}$ demonstrates a low frequency of tetramer ${ }^{+} \mathrm{T}$ cells among unstimulated $\mathrm{CD} 8^{+}$ $\mathrm{T}$ cells (Fig. 2B), which is typical for memory $\mathrm{T}$ cells after recovery. All tetramer ${ }^{+} \mathrm{T}$ cells were $\mathrm{CD} 45 \mathrm{RO}^{+}$and $\mathrm{CCR}^{+}$ prior to rechallenge (week 0; Fig. 2C) and thus represented central memory cells that circulate between lymphoid organs.

During the first 22 weeks of rechallenge, the frequencies of IFN- $\gamma$-producing cells were close to the frequencies of tetramer $^{+}$cells. For instance, 20 IFN- $\gamma$-producing cells per 100,000 PBMC in the ELISPOT assay translated to roughly $0.02 \%$ tetramer $^{+} \mathrm{CD}^{+} \mathrm{T}$ cells, with the ELISPOT assay usually picking up 1 in 10 to 1 in 3 cells. Also, a slight decrease in IFN- $\gamma$-producing cells from week 18 to week 20 to week 22 (Fig. 1D) paralleled a decrease in the number of tetramer ${ }^{+}$ cells during the same period (Fig. 2B). Whereas all tetramer ${ }^{+}$ cells were $\mathrm{CD} 45 \mathrm{RO}^{+}$prior to rechallenge, a significant proportion were $\mathrm{CD}^{4} 5 \mathrm{RO}^{-}$after rechallenge (Fig. 2C). These cells could represent either new effector cells or memory cells reverted from a CD45RO ${ }^{+}$phenotype to a $\mathrm{CD}_{45 \mathrm{RO}^{-}}$phenotype $(59,63)$. In addition, a new population of $\mathrm{CCR}^{-}$tetramer $^{+} \mathrm{T}$ cells, representing effector memory cells known to circulate between nonlymphoid tissues (48), became detectable (Fig. 2C).

Interestingly, the timing of the $\mathrm{CD}^{+} \mathrm{T}$-cell response differed significantly from that of the $\mathrm{CD}^{+}$T-cell response. Whereas IFN- $\gamma$-producing and proliferating $\mathrm{CD}^{+}{ }^{+} \mathrm{T}$ cells became undetectable in the circulation after inoculation of 3.2 $\mathrm{CID}_{50}$, i.e., as early as week 12 , the number of IFN- $\gamma$-producing $\mathrm{CD}^{+} \mathrm{T}$ cells decreased later, i.e., weeks 18 to 22 . Moreover, IFN- $\gamma$-producing and proliferating $\mathrm{CD} 4^{+} \mathrm{T}$ cells reappeared in the circulation immediately at the onset of viremia (week 22; Fig. 1A), whereas IFN- $\gamma$-producing $\mathrm{CD}^{+} \mathrm{T}$ cells were detectable 5 weeks later, at week 27 . Interestingly, more than $98 \%$ of the $\mathrm{CD}_{45 \mathrm{RO}^{+}}$tetramer $^{+} \mathrm{T}$ cells were $\mathrm{CCR}^{+}$ central memory cells at the time of viremia, when the frequency of tetramer ${ }^{+} \mathrm{T}$ cells was highest (week 23; Fig. 2B and C). When IFN- $\gamma$ production of $\mathrm{CD}^{+} \mathrm{T}$ cells became detectable at week 27 , more than $50 \%$ of the $\mathrm{CCR} 7^{+}$central memory cells had been replaced by CCR $7^{-}$effector memory cells (week 27; Fig. 2C). Thus, the $\mathrm{CD} 8^{+} \mathrm{T}$-cell response in the periphery appeared to trail the $\mathrm{CD} 4^{+} \mathrm{T}$-cell response by several weeks, and the appearance of functionally active $\mathrm{CD}^{+} \mathrm{T}$ cells was associated with a phenotypic change of the tetramer ${ }^{+}$population.

Peripheral blood immune response of Ch1552 during rechallenge. The same prospective analysis of humoral and cellular immune responses was performed for Ch1552 (Fig. 3). As in chimpanzee Ch4X0186, antibodies against HCV envelope glycoproteins were not detectable by ELISA at any time point 
A

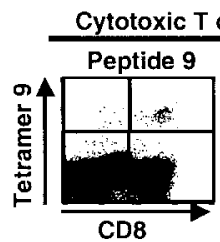

B

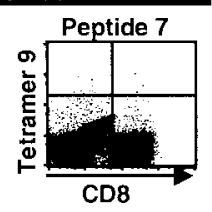

Cytotoxic T cell line specific for

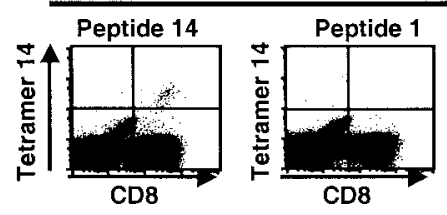

HCV Rechallenge
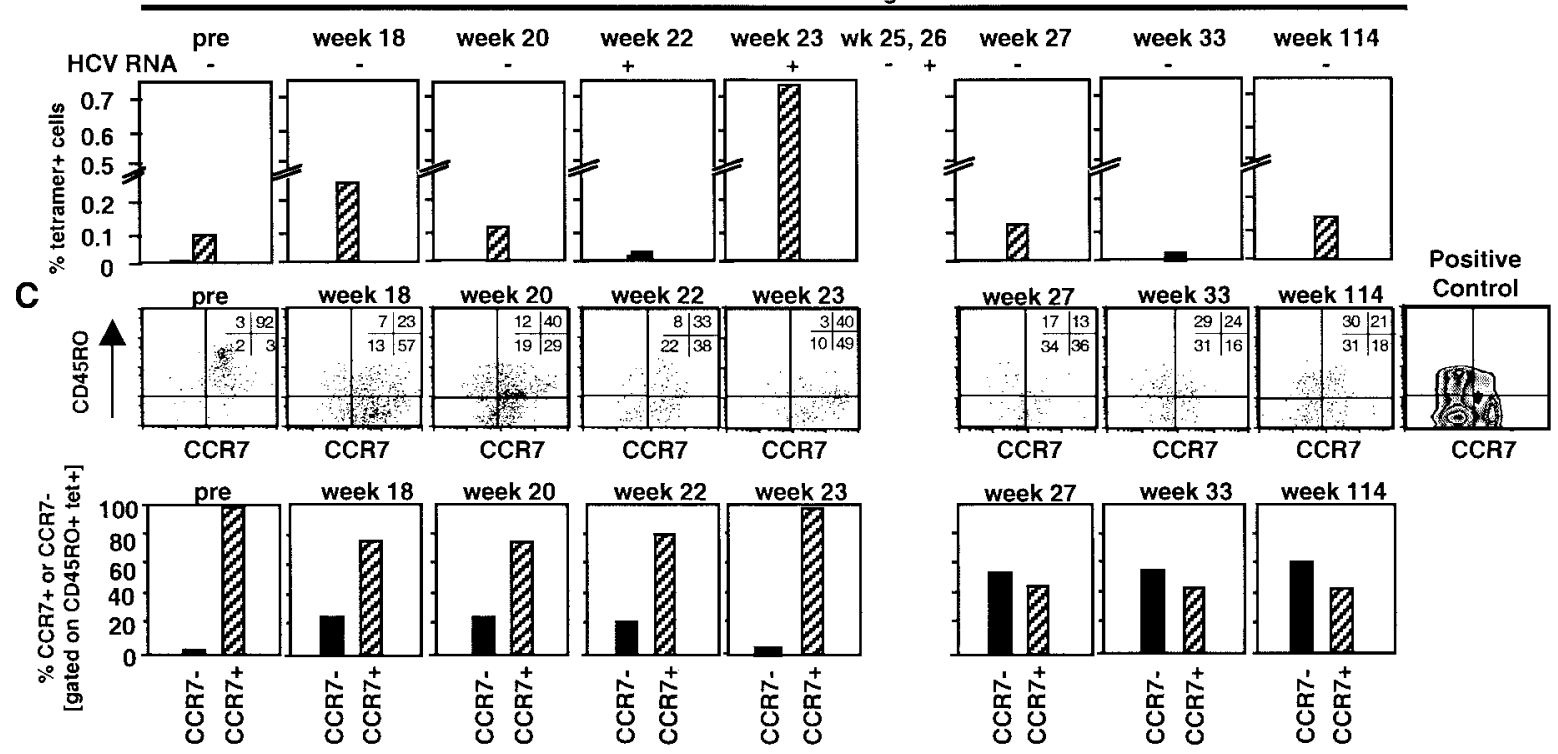

FIG. 2. Frequency and phenotype of tetramer ${ }^{+} \mathrm{T}$ cells in the blood of Ch4X0186 during rechallenge. (A) Specificity of Patr tetramers was confirmed by staining peptide-specific and nonspecific in vitro-expanded T-cell lines. (B) Direct ex vivo staining of PBMC from chimpanzee Ch4X0186. Staining was performed with a tetramer mixture due to the limited number of available PBMC. Tetramer 14 was part of this mixture because $\mathrm{T}$ cells of this specificity produced IFN- $\gamma$ during rechallenge (Fig. 1D). A tetramer with peptide 1 , the other peptide recognized by IFN- $\gamma$-producing T cells (Fig. 1D), did not fold and therefore could not be used. The frequency of tetramer ${ }^{+} \mathrm{T}_{\text {cells }}$ increased at week 23 , coinciding with detectable HCV RNA in the serum (Fig. 1A). n.t., not tested. (C) PBMC were stained directly ex vivo with tetramers (PE) and antibodies against CCR7 and CD4 and CD19 and CD45RO. Lymphocytes were gated based on side and forward scatter and a CD4 CD19 exclusion gate. Tetramer ${ }^{+} \mathrm{T}$ cells were gated and analyzed for CCR7 and CD45RO expression. To determine the cutoff of positivity, PBMC were stained for CD45RO and CCR7 without gating on tetramer ${ }^{+}$cells. In the dot plots, the numbers in each quadrant indicate the percentages of tetramer ${ }^{+}$ cells that do or do not express the respective surface markers. In the bar graphs, hatched bars indicate the percentages of $\mathrm{CCR}^{+} \mathrm{CD}^{+} \mathrm{RO}^{+}$ central memory cells and solid bars indicate the percentages of $\mathrm{CCR}^{-} \mathrm{CD}^{-} \mathrm{RO}^{+}$effector memory cells.

prior to or during $\mathrm{HCV}$ rechallenge. The RIBA was negative (Fig. 3A). In contrast, a multispecific, IFN- $\gamma^{+} \mathrm{T}$-cell response was detectable by ELISPOT analysis (Fig. 3B). As described for Ch4X0186, the frequency of IFN- $\gamma^{+} \mathrm{CD}^{+} \mathrm{T}$ cells decreased after injection with the low dose of $0.32 \mathrm{CID}_{50}$ (Fig. 3B), and, at the same time, there was a slight increase of IFN $-\gamma^{+} \mathrm{CD}^{+} \mathrm{T}$ cells (Fig. 3D) but no detectable change in the antibody response in RIBAs (Fig. 3A) and ELISAs (35).

Ch1552 then received 3.2 CID $_{50}$ and, 1 week later, became viremic for a period of 4 weeks. As described for Ch4X0186, viremia was rapidly cleared below the detection limit of realtime PCR, and this was associated with a vigorous IFN- $\gamma$ response to $\mathrm{HCV}$ proteins (week 7; Fig. 3B). Interestingly, the peak of IFN- $\gamma$-producing PBMC in the blood coincided precisely with the first time point (week 7) that tested negative for HCV RNA by real-time PCR. Moreover, Ch1552 appeared to be protected against the 10 -fold-higher $32-\mathrm{CID}_{50}$ rechallenge, which again stimulated IFN- $\gamma$ production by HCV-specific, circulating T cells in response to HCV proteins (week 10; Fig. 3B). As described for Ch4X0186, the RIBA turned from indeterminate to clearly positive at that time (Fig. 3A), with de- tectable HCV NS3- and NS4B-specific antibodies and a significant increase of the optical density in the NS3-specific ELISA (35) but undetectable antibodies against HCV envelope glycoproteins (not shown).

In contrast to what was found for Ch4X0186, however, we observed only weak proliferation of circulating $\mathrm{HCV}$-specific $\mathrm{T}$ cells, even during viremia (Fig. 3C). Moreover, IFN- $\gamma$ production of $\mathrm{HCV}$-specific $\mathrm{CD}^{+} \mathrm{T}$ cells decreased progressively during the prospective follow-up and was completely lost at weeks 22 and 24. At that time, viral recrudescence occurred and $\mathrm{HCV}$ remained intermittently detectable in the blood by real-time PCR and nested RT-PCR (Fig. 3A), concomitant with weak IFN- $\gamma$ responses of $\mathrm{HCV}$-specific $\mathrm{CD} 4^{+} \mathrm{T}$ cells (Fig. 3B). Consistent with the weaker proliferation of $\mathrm{HCV}$-specific $\mathrm{T}$ cells, the tetramer ${ }^{+} \mathrm{CD}^{+} \mathrm{T}$-cell population was smaller in Ch1552 (week 4; Fig. 4B) than in Ch4X0186 (week 23; Fig. 2B) and there were fewer tetramer ${ }^{+} \mathrm{CCR} 7^{+}$central memory cells (week 4; Fig. 4C) than in Ch4X0186 (week 23; Fig. 2C). Also, the number of IFN- $\gamma$-producing memory $\mathrm{T}$ cells did not increase as significantly as in Ch4X0186 and remained only 


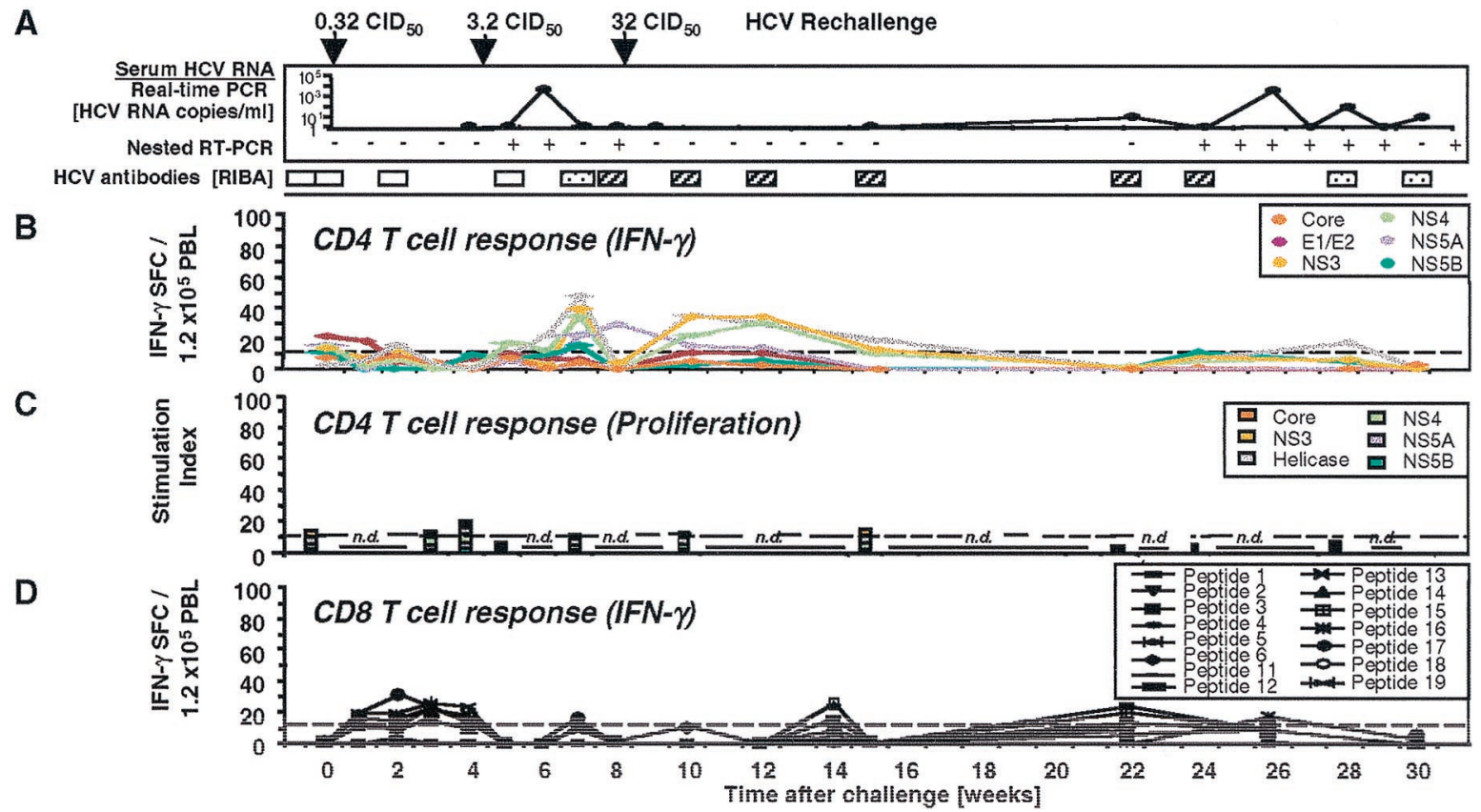

FIG. 3. HCV-specific $\mathrm{CD}^{+}$and $\mathrm{CD} 8^{+} \mathrm{T}$-cell responses of $\mathrm{Ch} 1552$ during $\mathrm{HCV}$ rechallenge. (A) Arrows, time points of intravenous inoculation. Presence $(+)$ or absence $(-)$ of virus below the detection limit of real-time PCR $(<400 \mathrm{HCV}$ RNA copies/ml $)$ was assessed by nested RT-PCR. $\square$, negative RIBA score (no HCV band observed); other RIBA scores are indicated as defined in the legend to Fig. 1. Only antibodies against HCV NS3 and NS4B were detected; all other antigens, including E1/E2 glycoproteins, tested negative. (B) Frequency of HCV-specific T cells that produce IFN- $\gamma$ in response to HCV proteins (ELISPOT analysis). Responses are indicated as specific spot-forming cells (SFC) per $1.2 \times$ $10^{5}$ peripheral blood lymphocytes (PBL) (number of SFC in the presence of antigen - number of SFC in the absence of antigen). (C) Proliferative T-cell response to HCV proteins, presented as in Fig. 1C. (D) Frequency of HCV-specific CD8 ${ }^{+} \mathrm{T}$ cells that produce IFN- $\gamma$ in response to $15 \mathrm{HCV}$ peptide epitopes (ELISPOT analysis). HCV peptides were selected according to the animal's Patr haplotype (38). Responses are indicated as in panel A.

slightly above the detection level of the ELISPOT assay (Fig. 3D).

The same pattern was observed during viral recrudescence at week 26 (Fig. 3 and Fig. 4). Again, the frequency of IFN$\gamma$-producing $\mathrm{T}$ cells increased slightly (Fig. 3B), but there was no evidence of proliferation (Fig. 3C). As regards the CD8 ${ }^{+}$ T-cell response, the phenotype of the tetramer ${ }^{+}$population changed from predominantly $\mathrm{CCR}^{+}$to predominantly CCR $7^{-}$when HCV recrudescence occurred at week 26 but the absolute number of $\mathrm{CD}_{45 \mathrm{RO}^{+}}$tetramer ${ }^{+}$cells remained very low (Fig. 4B and C). Thus, in addition to the effector functions of $\mathrm{HCV}$-specific $\mathrm{CD} 4^{+}$and $\mathrm{CD} 8^{+} \mathrm{T}$ cells, an increase in their absolute number appeared to be crucial for recovery and for prevention of $\mathrm{HCV}$ recrudescence.

Peripheral blood immune response of Ch1605 during rechallenge. The third chimpanzee (Ch1605) was rechallenged with a single dose of $100 \mathrm{CID}_{50}$, and viremia was quantifiable by real-time PCR 1 week after inoculation (Fig. 5A). As described for Ch4X0186 and Ch1552, viremia rapidly decreased below the detection level of real-time PCR and a single round RT-PCR (Fig. 5A). Also as described for the other two chimpanzees, antibodies against $\mathrm{HCV}$ envelope glycoproteins were not detectable at any time point during rechallenge and antibodies against NS3 and NS4B became detectable only when $\mathrm{HCV}$ was cleared, as shown by RIBAs turning from indeterminate to positive (Fig. 5A).

As in Ch4X0186, proliferative CD4 ${ }^{+} \mathrm{T}^{-}$-cell responses were clearly detectable and quite strong, with a maximum stimula- tion index of 90. However, these responses were not maintained at a level comparable to that for Ch4X0186. IFN- $\gamma$ production in response to $\mathrm{HCV}$ proteins and peptides (Fig. 5B and $\mathrm{D}$, respectively) was also significantly weaker than in Ch4X0186. Significant CD8 ${ }^{+}$T-cell responses were neither detectable by ELISPOT (Fig. 5D) nor by tetramer analysis (not shown), although this result should be viewed with caution because of the limited number of peptides available for this animal. Consistent with the weak immune response, nested RT-PCR remained intermittently positive (Fig. 5A), indicating that trace amounts of $\mathrm{HCV}$ below the threshold of quantitative RT-PCR $(<400$ copies $/ \mathrm{ml})$ were still present in the circulation of the chimpanzee. Collectively, the data from the three animals suggest a correlation between the vigor and sustenance of the cellular immune response and the virological course of infection.

Analysis of intrahepatic immune responses. Because HCVspecific $\mathrm{T}$ cells are thought to mediate their effector function at the site of infection, the liver, we next asked whether HCVspecific $\mathrm{T}$ cells could be isolated from liver biopsy samples during rechallenge. This was a relevant question, because infiltration of virus-specific $\mathrm{T}$ cells is generally associated with elevation of serum ALT activity in acute hepatitis C. However, none of the rechallenged chimpanzees displayed significantly elevated ALT activity during rechallenge. Furthermore, it was not known whether infiltration of a significant number of $\mathrm{HCV}$-specific $\mathrm{T}$ cells could occur during the very short period of rechallenge viremia. 
A

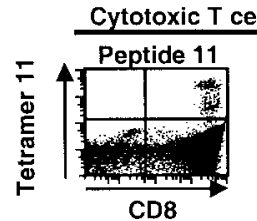

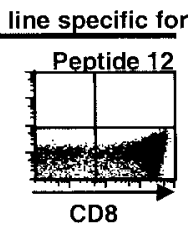

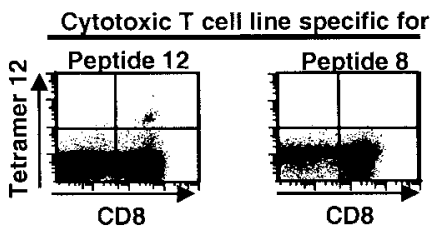

HCV Rechallenge
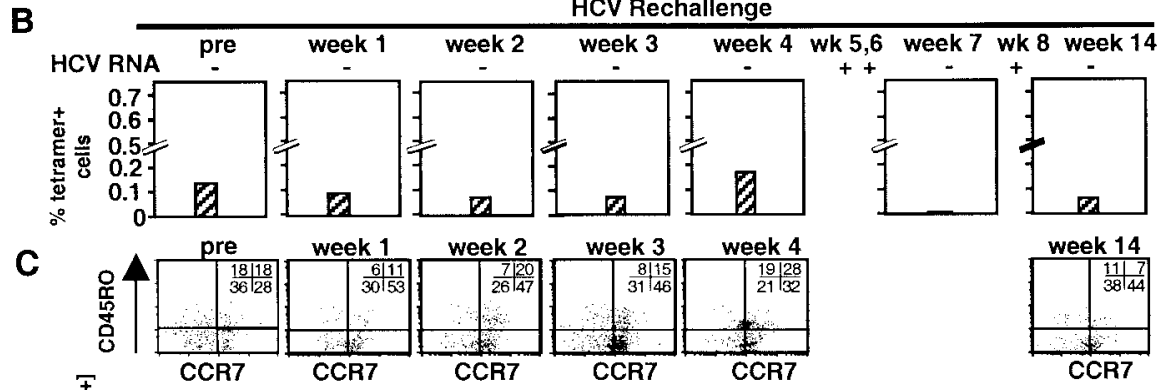

week 14
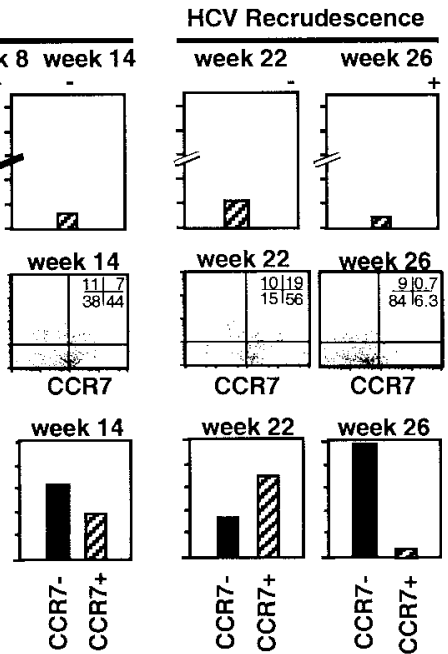

FIG. 4. Frequency and phenotype of tetramer ${ }^{+} \mathrm{T}$ cells in the blood of Ch1552 during rechallenge. (A) Specificity of Patr tetramers was confirmed by staining peptide-specific and nonspecific T-cell lines. (B) Direct ex vivo staining of PBMC from chimpanzee Ch1552. Staining was performed with a tetramer mixture due to the limited number of available PBMC. (C) PBMC were stained directly ex vivo with tetramers (PE) and antibodies against CCR7 and CD4 and CD19 and CD45RO. Lymphocytes were gated based on side and forward scatter and a CD4 CD19 exclusion gate. Tetramer ${ }^{+} \mathrm{T}$ cells were analyzed for CCR7 and CD45RO expression. Cutoffs were set as in Fig. 2C. In the dot plots, the numbers in each quadrant indicate the percentage of tetramer ${ }^{+}$cells that do or do not express the respective surface markers. In the bar graphs, hatched bars indicate the percentages of $\mathrm{CCR} 7^{+} \mathrm{CD} 45 \mathrm{RO}^{+}$central memory cells and solid bars indicate the percentages of $\mathrm{CCR}^{-} \mathrm{CD}^{-} 5 \mathrm{RO}^{+}$effector memory cells.

To answer these questions, we first analyzed the components of the intrahepatic infiltrate prospectively by ex vivo flow cytometry and then cloned liver-infiltrating lymphocytes in an antigen-nonspecific manner. Figure 6A shows the frequency of intrahepatic $\mathrm{CD}^{+} \mathrm{CD}^{-} 6^{-}$conventional T cells, $\mathrm{CD}^{-} \mathrm{CD}^{-} 6^{+}$ $\mathrm{NK}$ cells, and $\mathrm{CD}^{+}{ }^{+} \mathrm{CD} 56^{+}$lymphocytes. The $\mathrm{CD}^{+}{ }^{+} \mathrm{CD} 56^{+}$ population contains innate lymphocytes with $\mathrm{NK}$ cell markers as well as activation and memory markers and rapid effector functions and is predominantly present in peripheral tissues $(12,13)$. Whereas no significant change in relative and absolute numbers of liver-infiltrating cells was observed after Ch1552 was inoculated with $0.32 \mathrm{CID}_{50}$, a 20 -fold increase was observed after inoculation of $3.2 \mathrm{CID}_{50}$ (Fig. 6A). Specifically, the number of $\mathrm{CD}^{+} \mathrm{CD}^{-} 6^{-}$conventional $\mathrm{T}$ cells increased from $4.8 \times 10^{3} \mathrm{~T}$ cells $/ \mathrm{cm}$ of biopsy sample at week 4 to $95 \times$ $10^{3}$ cells/cm of biopsy sample at week 6 . In contrast, the frequency of cells of the innate immune response $\left(\mathrm{CD} 3^{-} \mathrm{CD} 56^{+}\right.$ and $\mathrm{CD}^{+} \mathrm{CD}^{+} 6^{+}$cells) increased only slightly. After HCV was cleared to levels below the threshold of nested RT-PCR in blood and liver biopsy samples, the number of liver-infiltrating cells decreased (Fig. 6A) and then reached second and third peaks at the time of HCV recrudescence (Fig. 6B). Similar intrahepatic immune responses were observed during rechallenge of Ch1605 with $100 \mathrm{CID}_{50}$, which resulted in an increase of the intrahepatic $\mathrm{CD}^{+} \mathrm{CD}^{-} 6^{-}$conventional T-cell population. Whereas the number of $\mathrm{CD}^{-} \mathrm{CD}^{-} 6^{+} \mathrm{NK}$ cells and $\mathrm{CD}^{+} \mathrm{CD}^{+} 6^{+}$lymphocytes decreased within 6 weeks after rechallenge, the number of intrahepatic $\mathrm{CD} 3{ }^{+} \mathrm{CD}_{5} 6^{-}$conven- tional $\mathrm{T}$ cells remained higher than in Ch1552, along with intermittent detection of small amounts of serum HCV RNA by nested RT-PCR. Collectively, the data indicate a more significant change in the number of intrahepatic conventional $\mathrm{T}$ cells than in the numbers of $\mathrm{CD}^{-} \mathrm{CD}^{-} 6^{+} \mathrm{NK}$ cells and $\mathrm{CD}^{+} \mathrm{CD}^{+} 6^{+}$lymphocytes during the period of viremia and thus suggest a role for the intrahepatic adaptive immune response.

To analyze specificity and effector function of intrahepatic $\mathrm{T}$ cells, liver-derived lymphocytes were isolated and cloned in an antigen-nonspecific manner with anti-CD3 and IL-2. Growing $\mathrm{T}$-cell lines were analyzed for $\mathrm{HCV}$-specific proliferation by using a panel of recombinant $\mathrm{HCV}$ antigens and for $\mathrm{HCV}$ specific cytotoxicity by using autologous PHA-stimulated blast target cells that had been infected with a recombinant vaccinia virus expressing the full-length $\mathrm{HCV}$ polyprotein with a sequence identical to the amino acid sequence of the rechallenge HCV. As described above for Ch4X0186 and in accordance with the literature (10), the frequency of HCV-specific T-cell lines was typically between 2 and $4 \%$ of all liver-derived T-cell lines after recovery and prior to rechallenge viremia. In contrast, up to $60 \%$ of the analyzed liver-derived cell lines were $\mathrm{HCV}$ specific during the viremic phase of $\mathrm{HCV}$ rechallenge of Ch1552. Effector functions consisted of HCV-specific proliferation (Fig. 6D) and IFN- $\gamma$ production (not shown). Although $22 \%$ of the expanded lines expressed CD8, none displayed $\mathrm{HCV}$-specific cytotoxicity, an observation that corresponded to the asymptomatic clinical course of the rechallenge. All HCV- 


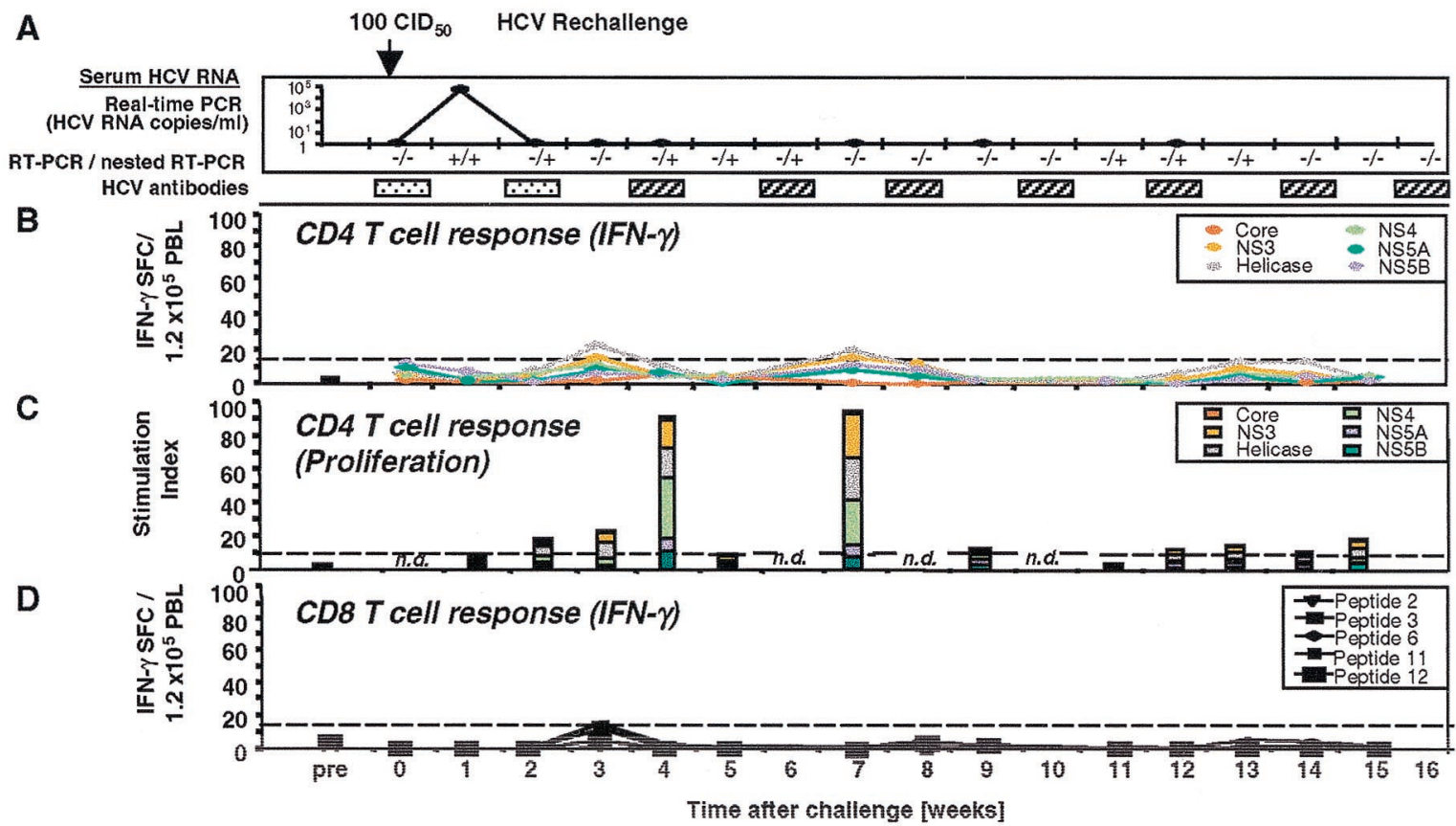

FIG. 5. HCV-specific $\mathrm{CD}^{+}$and $\mathrm{CD}^{+}$T-cell responses of Ch1605 during HCV rechallenge. (A) Arrows, time points of intravenous inoculation. Presence or absence of virus below the detection limit of real-time PCR $(<400 \mathrm{HCV}$ RNA copies/ml $)$ was assessed by nested RT-PCR $(+/+$, positive first and positive nested PCR; $-/+$, negative first and positive nested PCR; $-/-$, negative first and negative nested PCR). RIBA scores are indicated as described in the legend to Fig. 1. Only antibodies against HCV NS3 and NS4B were detected; all other antigens, including E1/E2 glycoproteins, tested negative. (B) Frequency of HCV-specific T cells that produce IFN- $\gamma$ in response to HCV proteins (ELISPOT analysis). Responses are indicated as specific spot-forming cells (SFC) per $1.2 \times 10^{5}$ peripheral blood lymphocytes (PBL) (number of SFC in the presence of antigen - number of SFC in the absence of antigen). (C) Proliferative T-cell response to HCV proteins, presented as in Fig. 1C. (D) Frequency of $\mathrm{HCV}$-specific $\mathrm{CD}^{+} \mathrm{T}$ cells that produce IFN- $\gamma$ in response to five $\mathrm{HCV}$ peptide epitopes (ELISPOT analysis). HCV peptides were selected according to the animal's Patr haplotype (38). Responses are indicated as in panel A.

specific T-cell lines were exclusively targeted against nonstructural proteins (Fig. 6D). Importantly, although these vigorous HCV-specific immune responses in the liver of Ch1552 coincided with clearance of the $3.2-\mathrm{CID}_{50}$ inoculum and apparent protection against the $32-\mathrm{CID}_{50}$ inoculum, they decreased over time in both the liver (not shown) and the blood (Fig. 3), and subsequently HCV recrudescence occurred.

\section{DISCUSSION}

Although individuals that spontaneously recovered have been shown to maintain $\mathrm{HCV}$-specific cellular rather than humoral immune responses (53), the precise activation requirements, kinetics, and effector functions of different memory T-cell subsets during reexposure to HCV are not known.

In this study, all rechallenged chimpanzees rapidly cleared $\mathrm{HCV}$ to levels below the threshold of quantitative RT-PCR, did not develop any evidence of liver disease, and thus displayed protective immunity. This is consistent with previous studies that demonstrated a high rate of HCV clearance in chimpanzees (2). In general, chimpanzees appear to clear HCV more frequently than humans (60), which might be due to an underestimation of the number of recovered subjects who lose HCV-specific antibodies (53). However, consistent with the apparent lack of antibodies against HCV envelope glycoproteins, sterilizing immunity was not observed. Moreover, contrary to previous studies $(3,62)$, we report that HCV is not necessarily completely eradicated even if it remains undetectable in blood and liver biopsy samples by nested RTPCR (detection level of 40 RNA copies/ml) for up to 4 months. In fact, only one (Ch4X0186) of three animals remained HCV negative by nested RT-PCR for more than 1.5 years of followup. In the second animal, Ch1552, recrudescence of trace amounts of $\mathrm{HCV}$ was observed 4 months after initial $\mathrm{HCV}$ clearance from blood. In the third animal (Ch1605), minute amounts of circulating HCV remained intermittently detectable by nested RT-PCR.

These findings are in line with a clinical report on a patient who initially recovered from acute hepatitis $\mathrm{C}$ with strong cellular immune responses and complete HCV clearance according to serum RT-PCR (21). After 4 months, however, $\mathrm{HCV}$-specific cellular immune responses decreased and $\mathrm{HCV}$ RNA reappeared (21). Thus, minute amounts of HCV may remain at least intermittently detectable by sensitive molecular techniques in some recovered patients and chimpanzees. This is supported by a recent report that describes picograms of IFN- $\alpha$ in the serum of a rechallenged chimpanzee (62), suggesting that it was induced by double-stranded HCV RNA replicative intermediates. Indeed, when the authors employed RT-PCR capable of detecting less than $30 \mathrm{HCV}$ RNA copies/ $\mathrm{ml}$, they observed extremely weak viremia for 2 weeks after rechallenge (62). Thus, if trace amounts of HCV remain intermittently detectable in the circulation, HCV would not differ from other infectious agents, such as $\operatorname{HBV}(8,46,47)$, cyto- 

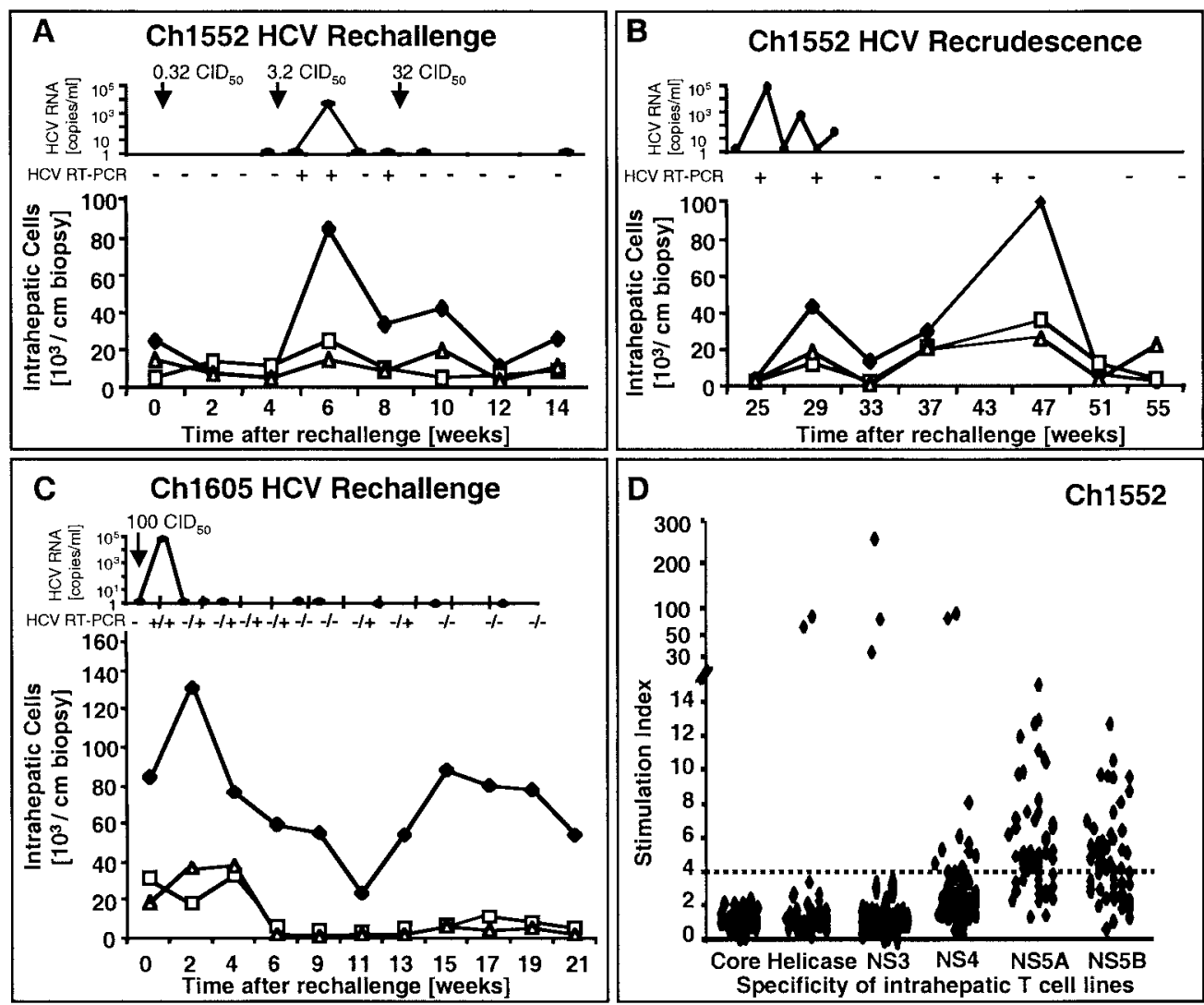

FIG. 6. Intrahepatic immune response of Ch1552 and Ch1605 during HCV rechallenge. (A and B) Intrahepatic immune response of Ch1552 during HCV rechallenge (A) and HCV recrudescence (B). Presence $(+)$ or absence $(-)$ of virus below the detection limit of real-time PCR $(<400$ HCV RNA copies/ml) was assessed by nested RT-PCR. The numbers of intrahepatic CD3 ${ }^{-} \mathrm{CD}^{2} 6^{+}$conventional lymphocytes $(\bullet), \mathrm{CD}^{-} \mathrm{CD}^{+} 6^{+}$ NK cells $(\square)$, and $\mathrm{CD}^{+}{ }^{+} \mathrm{CD} 6^{+}$lymphocytes $(\triangle)$ per $\mathrm{cm}$ of biopsy sample were determined by flow cytometry. Arrows, time points of intravenous inoculation. Presence or absence of virus in the serum was assessed by nested RT-PCR. (C) Intrahepatic immune response of Ch1605 during HCV rechallenge. Symbols are used as in panel A. Presence or absence of virus in the serum according to real-time PCR and first- and second-round RT-PCR is indicated as in Fig. 5A. (D) Antigen specificity of intrahepatic T cells of Ch1552 during rechallenge. Liver-derived T cells were expanded with anti-CD3 and IL-2 and tested for antigen specificity in proliferation and cytotoxicity assays. Dashed line, cutoff for a positive proliferation assay. None of the cell lines tested positive in the cytotoxicity assay.

megalovirus (24), and herpes simplex virus (52). Further prospective studies are needed to evaluate how many individuals who have recovered from HCV still harbor trace amounts of virus.

Importantly, the vigor and timing of the cellular immune response correlated closely with the virological course and outcome of HCV rechallenge. Vigorous proliferation of $\mathrm{HCV}$ specific $\mathrm{T}$ cells was associated with rapid $\mathrm{HCV}$ control in Ch4X0186, whereas weak proliferation of HCV-specific T cells was associated with persistence of trace amounts of $\mathrm{HCV}$ in Ch1605, and loss of proliferative HCV-specific T-cell responses was associated with HCV recrudescence in Ch1552. These data are in accordance with the crucial role of $\mathrm{T}$ cells in the control of viruses such as HBV (46), human immunodeficiency virus (5), and cytomegalovirus (27) and are in line with previous reports that demonstrate $\mathrm{HCV}$-specific cellular immune responses in the blood $(3,35)$ and in the livers $(10,35$, 54) of HCV-infected chimpanzees.

Notably, in the present study, the animal that had recovered for the longest time (Ch4X0186) displayed the strongest cellular immune response during rechallenge and was also the only animal that completely eradicated the virus within 4 weeks of rechallenge and remained negative by RT-PCR for more than 1.5 years of follow-up. Several explanations are possible. First, Ch4X0186 was the only animal that recovered from infection with passaged $\mathrm{H} 77$ serum, which contained HCV quasispecies. Thus, it is possible that multiple $\mathrm{HCV}$ quasispecies induced stronger immune responses than clonal virus. Second, repeated exposure of Ch4X0186 to very-low-dose inocula may have strengthened the T-cell response, as also suggested by human studies $(29,49)$. This hypothesis is further supported by the observed sensitivity of $\mathrm{HCV}$-specific $\mathrm{CD} 4^{+}$memory $\mathrm{T}$ cells to very-low-dose inocula (Fig. 1 and 3 ), which can be explained by the lower activation threshold of memory cells than of naive cells (43). Third, the presence of $\mathrm{CD}^{+}{ }^{+}$memory T-cell responses to subinfectious rechallenge doses in Ch4X0186 and Ch1552 is compatible with recognition of soluble or particulate antigen in the absence of replicating virus. Although the humoral immune response did not change significantly in response to subinfectious rechallenge doses, even a low titer of $\mathrm{HCV}$-specific antibodies against nonstructural proteins (NS3 and NS4B) could help to enhance the immune response to 
small amounts of antigen, and all chimpanzees showed similar quantitative and qualitative changes of the humoral immune response to viremia. Small amounts of antigen, presumably released by infected hepatocytes or by hepatocytes lysed by cytotoxic $\mathrm{T}$ cells, could be opsonized by antibodies for uptake by professional antigen-presenting cells, which subsequently transport the antigen to the regional lymph nodes and stimulate $\mathrm{T}$ cells. Fourth, viral escape by mutations in T-cell epitopes, as recently described for persistently $\mathrm{HCV}$-infected patients (6) and chimpanzees $(16,61)$, could potentially explain $\mathrm{HCV}$ recrudescence in Ch1552 and trace amounts of circulating HCV in Ch1605. Unfortunately, HCV titers were too low to obtain sequence data for these two animals. Even if viral escape occurred, however, one may speculate that it might not have affected all $\mathrm{T}$-cell recognition sites or that it might not have been compatible with enhanced viral replication because $\mathrm{HCV}$ titers never increased to high levels during the reported follow-up.

In contrast to $\mathrm{HCV}$-specific $\mathrm{CD} 4^{+} \mathrm{T}$-cell responses, significant $\mathrm{HCV}$-specific $\mathrm{CD} 8^{+} \mathrm{T}$-cell responses were detectable only in the peripheral blood of one animal (Ch4X0186) and cytotoxicity was not detectable for any of the cloned, biopsy sample-derived T-cell lines of Ch4X0186 and Ch1552. This observation is in line with the report that the vigor of the $\mathrm{CD} 8^{+}$ $\mathrm{T}$-cell response parallels serum ALT levels and liver disease in acute hepatitis $\mathrm{C}(22,32)$ and the finding that none of the rechallenged chimpanzees in the present study displayed any evidence of liver disease. Nevertheless, it is difficult to draw final conclusions about the relative vigor and the relative roles of $\mathrm{CD}^{+}{ }^{+}$and $\mathrm{CD}^{+}{ }^{+} \mathrm{T}$-cell responses, because the $\mathrm{CD} 4^{+} \mathrm{T}$-cell response was assessed much more completely than the $\mathrm{CD} 8^{+}$ $\mathrm{T}$-cell response. The tetramer assay is a direct determination of the frequency of antigen-specific $\mathrm{T}$ cells but does not assess how $\mathrm{CD}^{+} \mathrm{T}$ cells would respond to endogenously processed antigen. Also, because individual $\mathrm{HCV}$ peptides were used to analyze the $\mathrm{CD}^{+} \mathrm{T}$-cell response, the possibility that additional and/or different $\mathrm{HCV}$ epitopes were targeted by $\mathrm{CD} 8^{+}$ $\mathrm{T}$ cells cannot be excluded (31). Finally, our analysis of the $\mathrm{T}$-cell response is also influenced by redistribution and migration of $\mathrm{CD}^{+} \mathrm{T}$ cells between blood, lymph nodes, and liver. The liver is unique among organs in that it harbors its own population of lymphocytes, and evidence suggests that part of the intrahepatic immune response is due to locally derived and in situ-differentiated cells $(9,39)$.

Despite the difficulty of comparing the vigor of $\mathrm{HCV}$-specific $\mathrm{CD}^{+}{ }^{+}$and $\mathrm{CD}^{+}$responses, however, there was a clear and interesting difference in the timing of both responses in the animal with the strongest immune response. Whereas HCVspecific, IFN- $\gamma$-producing, proliferating $\mathrm{CD}^{+}{ }^{+} \mathrm{T}$ cells were detectable in the circulation immediately at the onset of viremia, IFN- $\gamma$-producing $\mathrm{CD}^{+} \mathrm{T}$ cells were not detectable until week 27 despite of an earlier increase in the number of tetramer $^{+}$cells. These data are reminiscent of functional impairment of activated virus-specific $\mathrm{CD}^{+} \mathrm{T}$ cells in acute $\mathrm{HBV}$ (33), $\operatorname{HCV}(23,32,55)$, and lymphocytic choriomeningitis virus infections (19). In those cases, impairment of $\mathrm{CD}^{+} \mathrm{T}$-cell activity was attributed to high viral load and recovered after viral clearance, whereas in the present study HCV was barely detectable by real-time PCR. Although only a single chimpanzee displayed an immune response that was vigorous enough to allow the performance of this kind of analysis in the present study, the results may offer an alternative explanation for the functional impairment or "stunned" phenotype described for effector cells in acute $\mathrm{HCV}$ infection $(32,55)$. At the time of viremia, all tetramer ${ }^{+}$cells were $\mathrm{CCR} 7^{+}$, and a consecutive switch from $\mathrm{CCR}^{+}$central memory cells to $\mathrm{CCR} 7^{-}$effector memory cells was followed by IFN- $\gamma$ production. This is in line with the previous report that $\mathrm{CCR} 7^{+}$central memory cells do not exert immediate effector function and that $\mathrm{CCR} 7^{-}$effector memory cells migrate to the site of infection $(48,56)$. Collectively, these data suggest that this phenotype may represent a normal phase in the life cycle and migration of antigen-specific $\mathrm{T}$ cells.

In conclusion, HCV-specific T cells of chimpanzees that had recovered from $\mathrm{HCV}$ infection responded rapidly to low levels of $\mathrm{HCV}$ antigen and this response correlated with reduced viremia, earlier viral clearance, and markedly less liver disease than in primary HCV infection. Despite viral clearance below the detection level of real-time PCR, however, HCV remained intermittently detectable by nested RT-PCR in one animal and another animal experienced HCV recrudescence 4 months after initial viral clearance. These different patterns correlated with the vigor and maintenance of the HCV-specific T-cell response.

\section{ACKNOWLEDGMENTS}

This study was supported by U.S. Public Health Service grant CA85883-01 from the NIH (to C.M.R.) and by the NIDDK and CBER intramural research programs.

We thank Estella Jones, Krishna Murthy, and the staff of the animal care facilities for support; the NIAID Tetramer Facility of the NIH AIDS Research and Reference Reagent Program for synthesis of Patr tetramers; and Tom Wynn, Tobias Manigold, and Vito Racanelli for critical reading of the manuscript.

\section{REFERENCES}

1. Altman, J., P. A. H. Moss, P. Goulder, D. Barouch, M. McHeyzer-Williams, J. I. Bell, A. J. McMichael, and M. M. Davis. 1996. Phenotype analysis of antigen specific T lymphocytes. Science 274:94-96.

2. Bassett, S. E., K. M. Brasky, and R. E. Lanford. 1998. Analysis of hepatitis $\mathrm{C}$ virus-inoculated chimpanzees reveals unexpected clinical profiles. J. Virol. 72:2589-2599.

3. Bassett, S. E., B. Guerra, K. Brasky, E. Miskovsky, M. Houghton, G. R. Klimpel, and R. E. Lanford. 2001. Protective immune response to hepatitis $\mathrm{C}$ virus in chimpanzees rechallenged following clearance of primary infection. Hepatology 33:1479-1487.

4. Botarelli, P., M. R. Brunetto, M. A. Minutello, P. Calvo, D. Unutmaz, A. J. Weiner, Q.-L. Choo, J. R. Shuster, G. Kuo, F. Bonino, M. Houghton, and S. Abrignani. 1993. T-lymphocyte response to hepatitis $\mathrm{C}$ virus in different clinical courses of infection. Gastroenterology 104:580-587.

5. Carmichael, A., X. Jin, P. Sissons, and L. Borysiewicz. 1993. Quantitative analysis of the human immunodeficiency virus type 1 (HIV-1)-specific cytotoxic T lymphocyte (CTL) response at different stages of HIV-1 infection: differential CTL responses to HIV-1 and Epstein-Barr virus in late disease. J. Exp. Med. 177:249-256.

6. Chang, K. M., B. Rehermann, J. G. McHutchison, C. Pasquinelli, S. Southwood, A. Sette, and F. V. Chisari. 1997. Immunological significance of cytotoxic $\mathrm{T}$ lymphocyte epitope variants in patients chronically infected by the hepatitis C virus. J. Clin. Investig. 100:2376-2385.

7. Chang, K. M., R. Thimme, J. J. Melpolder, D. Oldach, J. Pemberton, J. Moorhead-Loudis, J. G. McHutchison, H. J. Alter, and F. V. Chisari. 2001. Differential CD4 and CD8 T-cell responsiveness in hepatitis C virus infection. Hepatology 33:267-276.

8. Chazouilleres, O., D. Mamish, M. Kim, K. Carey, L. Ferrell, J. P. Roberts, N. L. Ascher, and T. L. Wright. 1994. "Occult" hepatitis B virus as source of infection in liver transplant recipients. Lancet 343:142-146.

9. Collins, C., S. Norris, G. McEntee, O. Traynor, L. Bruno, H. von Boehmer, J. Hegarty, and C. O'Farrelly. 1996. RAG1, RAG2 and pre-T cell receptor alpha chain expression by adult human hepatic $\mathrm{T}$ cells: evidence for extrathymic T cell maturation. Eur. J. Immunol. 26:3114-3118. 
10. Cooper, S., A. L. Erickson, E. J. Adams, J. Kansopon, A. J. Weiner, D. Y Chien, M. Houghton, P. Parham, and C. M. Walker. 1999. Analysis of a successful immune response against hepatitis C virus. Immunity 10:439-449.

11. Diepolder, H. M., R. Zachoval, R. M. Hoffmann, A. Wierenga, T. Santantonio, M.-C. Jung, D. Eichenlaub, and G. R. Pape. 1995. Possible mechanism involving $\mathrm{T}$ lymphocyte response to non-structural protein 3 in viral clearance in acute hepatitis $\mathrm{C}$ virus infection. Lancet 346:1006-1007.

12. Doherty, D. G., S. Norris, L. Madrigal-Estebas, G. McEntee, O. Traynor, J. E. Hegarty, and C. O'Farrelly. 1999. The human liver contains multiple populations of $\mathrm{NK}$ cells, $\mathrm{T}$ cells, and $\mathrm{CD} 3{ }^{+} \mathrm{CD}_{5} 6^{+}$natural $\mathrm{T}$ cells with distinct cytotoxic activities and Th1, Th2, and Th0 cytokine secretion patterns. J. Immunol. 163:2314-2321.

13. Doherty, D. G., and C. O'Farrelly. 2000. Innate and adaptive lymphoid cells in the human liver. Immunol. Rev. 174:5-20.

14. Domena, J. D., A. M. Little, A. J. Madrigal, W. H. Hildebrand, L. JohnstonDow, E. du Toit, W. B. Bias, and P. Parham. 1993. Structural heterogeneity in HLA-B70, a high-frequency antigen of black populations. Tissue Antigens 42:509-517.

15. Erickson, A. L., M. Houghton, Q. L. Choo, A. J. Weiner, R. Ralston, E. Muchmore, and C. M. Walker. 1993. Hepatitis C virus-specific CTL responses in the liver of chimpanzees with acute and chronic hepatitis C. J. Immunol. 151:4189-4199.

16. Erickson, A. L., Y. Kimura, S. Igarashi, J. Eichelberger, M. Houghton, J. Sidney, D. McKinney, A. Sette, A. L. Hughes, and C. M. Walker. 2001. The outcome of hepatitis $\mathrm{C}$ virus infection is predicted by escape mutations in epitopes targeted by cytotoxic T lymphocytes. Immunity 15:883-895.

17. Farci, P., H. J. Alter, S. Govindarajan, D. C. Wong, R. Engle, R. R. Lesniewski, I. K. Mushahwar, S. M. Desai, R. H. Miller, and N. Ogata. 1992 Lack of protective immunity against reinfection with hepatitis $\mathrm{C}$ virus. Science 258:135-140.

18. Ferrari, C., A. Valli, L. Galati, A. Penna, P. Scaccaglia, T. Guiberti, C. Schianchi, G. Missale, M. G. Marin, and F. Fiaccadori. 1994. T-cell response to structural and nonstructural hepatitis $\mathrm{C}$ virus antigens in persistent and self-limited hepatitis C virus infections. Hepatology 19:286-295.

19. Gallimore, A., A. Glithero, A. Godkin, A. C. Tissot, A. Plückthun, T. Elliott, H. Hengartner, and R. Zinkernagel. 1998. Induction and exhaustion of lymphocytic choriomeningitis virus-specific cytotoxic $\mathrm{T}$ lymphocytes visualized using soluble tetrameric major histocompatibility complex class I-peptide complexes. J. Exp. Med. 187:1383-1393.

20. Garboczi, D. N., D. T. Hung, and D. C. Wiley. 1992. HLA-A2-peptide complexes: refolding and crystallization of molecules expressed in Escherichia coli and complexed with single antigenic peptides. Proc. Natl. Acad. Sci. USA 89:3429-3433.

21. Gerlach, J. T., H. M. Diepolder, M. C. Jung, N. H. Gruener, W. W. Schraut, R. Zachoval, R. Hoffmann, C. A. Schirren, T. Santantonio, and G. R. Pape. 1999. Recurrence of hepatitis C virus after loss of virus-specific CD ${ }^{+}{ }^{+}$-cell response in acute hepatitis C. Gastroenterology 117:933-941.

22. Gruener, N. H., T. J. Gerlach, M. C. Jung, H. M. Diepolder, C. A. Schirren, W. W. Schraut, R. Hoffmann, R. Zachoval, T. Santantonio, M. Cucchiarini, A. Cerny, and G. R. Pape. 2000. Association of hepatitis C virus-specific $\mathrm{CD}^{+} \mathrm{T}$ cells with viral clearance in acute hepatitis C. J. Infect. Dis. 181: 1528-1536.

23. Gruener, N. H., F. Lechner, M. C. Jung, H. Diepolder, T. Gerlach, G. Lauer, B. Walker, J. Sullivan, R. Phillips, G. R. Pape, and P. Klenerman. 2001 Sustained dysfunction of antiviral $\mathrm{CD} 8^{+} \mathrm{T}$ lymphocytes after infection with hepatitis C virus. J. Virol. 75:5550-5558.

24. Jordan, M. C. 1978. Murine models of cytomegalovirus latency, p. 805-810 In J. G. Stevens, G. J. Todaro, and C. F. Fox (ed.), Persistent viruses. Academic Press, New York, N.Y.

25. Kolykhalov, A., E. Agapov, K. Blight, K. Mihalik, S. Feinstone, and C. Rice. 1997. Transmission of hepatitis $\mathrm{C}$ by intrahepatic inoculation with transcribed RNA. Science 277:570-574.

26. Kolykhalov, A. A., K. Mihalik, S. M. Feinstone, and C. M. Rice. 2000 Hepatitis $\mathrm{C}$ virus-encoded enzymatic activities and conserved RNA elements in the $3^{\prime}$ nontranslated region are essential for virus replication in vivo. J. Virol. 74:2046-2051.

27. Komanduri, K. V., M. N. Viswanathan, E. D. Wieder, D. K. Schmidt, B. M. Bredt, M. A. Jacobson, and J. M. McCune. 1998. Restoration of cytomegalovirus-specific CD4 ${ }^{+}$T-lymphocyte responses after ganciclovir and highly active antiretroviral therapy in individuals infected with HIV-1. Nat. Med. 4:953-956.

28. Koziel, M. J., D. Dudley, N. Afdhal, A. Grakoui, C. M. Rice, Q. L. Choo, M. Houghton, and B. D. Walker. 1995. HLA class I-restricted cytotoxic T lymphocytes specific for hepatitis $\mathrm{C}$ virus. Identification of multiple epitopes and characterization of patterns of cytokine release. J. Clin. Investig. 96:23112321.

29. Koziel, M. J., D. K. H. Wong, D. Dudley, M. Houghton, and B. D. Walker. 1997. Hepatitis C virus-specific cytolytic T lymphocyte and $\mathrm{T}$ helper cell responses in seronegative persons. J. Infect. Dis. 176:859-866.

30. Lai, M. E., A. P. Mazzoleni, F. Argiolu, S. De Virgilis, A. Balestrieri, R. H. Purcell, A. Cao, and P. Farci. 1994. Hepatitis C virus in multiple episodes of acute hepatitis in polytransfused thalassaemic children. Lancet 343:388-390.
31. Lauer, G. M., K. Ouchi, R. T. Chung, T. N. Nguyen, C. L. Day, D. R. Purkis, M. Reiser, A. Y. Kim, M. Lucas, P. Klenerman, and B. D. Walker. 2002 Comprehensive analysis of $\mathrm{CD}^{+} \mathrm{T}$-cell responses against hepatitis $\mathrm{C}$ virus reveals multiple unpredicted specificities. J. Virol. 76:6104-6113.

32. Lechner, F., D. K. Wong, P. R. Dunbar, R. Chapman, R. T. Chung, P. Dohrenwend, G. Robbins, R. Phillips, P. Klenerman, and B. D. Walker. 2000. Analysis of successful immune responses in persons infected with hepatitis C virus. J. Exp. Med. 191:1499-1512.

33. Maini, M. K., C. Boni, G. S. Ogg, A. S. King, S. Reignat, C. K. Lee, J. R. Larrubia, G. J. Webster, A. J. McMichael, C. Ferrari, R. Williams, D. Vergani, and A. Bertoletti. 1999. Direct ex vivo analysis of hepatitis B virusspecific $\mathrm{CD}^{+} \mathrm{T}$ cells associated with the control of infection. Gastroenterology 117:1386-1396.

34. Major, M. E., K. Mihalik, J. Fernandez, J. Seidman, D. Kleiner, A. A. Kolykhalov, C. M. Rice, and S. M. Feinstone. 1999. Long-term follow-up of chimpanzees inoculated with the first infectious clone for hepatitis $\mathrm{C}$ virus. J. Virol. 73:3317-3325.

35. Major, M. E., K. Mihalik, M. Puig, B. Rehermann, M. Nascimbeni, C. M. Rice, and S. M. Feinstone. 2002. Previously infected and recovered chimpanzees exhibit rapid responses that control HCV replication upon rechallenge. J. Virol. 76:6586-6595.

36. Mehta, S. H., A. Cox, D. R. Hoover, X. H. Wang, Q. Mao, S. Ray, S. A. Strathdee, D. Vlahov, and D. L. Thomas. 2002. Protection against persistence of hepatitis C. Lancet 359:1478-1483.

37. Missale, G., R. Bertoni, V. Lamonaca, A. Valli, M. Massari, C. Mori, M. G. Rumi, M. Houghton, F. Fiaccadori, and C. Ferrari. 1996. Different clinical behaviors of acute hepatitis $\mathrm{C}$ virus infection are associated with different vigor of the anti-viral cell-mediated immune response. J. Clin. Investig. 98:706-714.

38. Mizukoshi, E., M. Nascimbeni, J. B. Blaustein, K. Mihalik, C. M. Rice, T. J. Liang, S. M. Feinstone, and B. Rehermann. 2002. Molecular and immunological significance of chimpanzee major histocompatibility complex haplotypes for hepatitis $\mathrm{C}$ virus immune response and vaccination studies. J. Virol. 76:6093-6103.

39. Norris, S., C. Collins, D. G. Doherty, F. Smith, G. McEntee, O. Traynor, N. Nolan, J. Hegarty, and C. O'Farrelly. 1998. Resident human hepatic lymphocytes are phenotypically different from circulating lymphocytes. J. Hepatol. 28:84-90.

40. Nuti, S., D. Rosa, N. M. Valiante, G. Saletti, M. Caratozzolo, P. Dellabona, V. Barnaba, and S. Abrignani. 1998. Dynamics of intra-hepatic lymphocytes in chronic hepatitis C: enrichment for Valpha $24^{+} \mathrm{T}$ cells and rapid elimination of effector cells by apoptosis. Eur. J. Immunol. 28:3448-3455.

41. Okamoto, H., M. Kojima, S. Okada, H. Yoshizawa, H. Iizuka, T. Tanaka, E. E. Muchmore, D. A. Peterson, Y. Ito, and S. Mishiro. 1992. Genetic drift of hepatitis $\mathrm{C}$ virus during an 8.2-year infection in a chimpanzee: variability and stability. Virology 190:894-899.

42. Pancholi, P., D. H. Lee, Q. Liu, C. Tackney, P. Taylor, M. Perkus, L. Andrus, B. Brotman, and A. M. Prince. 2001. DNA prime/canarypox boost-based immunotherapy of chronic hepatitis B virus infection in a chimpanzee. Hepatology 33:448-454

43. Pihlgren, M., P. M. Dubois, M. Tomkowiak, T. Sjogren, and J. Marvel. 1996. Resting memory $\mathrm{CD}^{+} \mathrm{T}$ cells are hyperreactive to antigenic challenge in vitro. J. Exp. Med. 184:2141-2151.

44. Prince, A. M., B. Brotman, T. Huima, D. Pascual, M. Jaffery, and G. Inchauspe. 1992. Immunity in hepatitis C infection. J. Infect. Dis. 165:438-443.

45. Puig, M., K. Mihalik, M. W. Yu, S. M. Feinstone, and M. E. Major. 2002. Sensitivity and reproducibility of HCV quantification in chimpanzee sera using TaqMan real-time PCR assay. J. Virol. Methods 105:253-263.

46. Rehermann, B., C. Ferrari, C. Pasquinelli, and F. V. Chisari. 1996. The hepatitis B virus persists for decades after patients' recovery from acute viral hepatitis despite active maintenance of a cytotoxic T-lymphocyte response. Nat. Med. 2:1104-1108.

47. Rehermann, B., D. Lau, J. Hoofnagle, and F. V. Chisari. 1996. Cytotoxic T lymphocyte responsiveness after resolution of chronic hepatitis B virus infection. J. Clin. Investig. 97:1655-1665.

48. Sallusto, F., D. Lenig, R. Forster, M. Lipp, and A. Lanzavecchia. 1999. Two subsets of memory T lymphocytes with distinct homing potentials and effector functions. Nature 401:708-712.

49. Scognamiglio, P., D. Accapezzato, A. Casciani, A. Cacciani, M. Artini, G. Bruno, M. L. Chircu, J. Sidney, S. Southwood, S. Abrignani, A. Sette, and V. Barnaba. 1999. Presence of effector $\mathrm{CD}^{+} \mathrm{T}$ cells in hepatitis $\mathrm{C}$ virusexposed healthy seronegative donors. J. Immunol. 162:6681-6689.

50. Seeff, L. B. 2002. Natural history of chronic hepatitis C. Hepatology 36:S35S46.

51. Sprent, J., J. F. Miller, and G. F. Mitchell. 1971. Antigen-induced selective recruitment of circulating lymphocytes. Cell. Immunol. 2:171-181.

52. Stevens, J. G., and M. L. Cook. 1971. Latent herpes simplex virus in spinal ganglia of mice. Science 173:843-845.

53. Takaki, A., M. Wiese, G. Maertens, E. Depla, U. Seifert, A. Liebetrau, J. L. Miller, M. P. Manns, and B. Rehermann. 2000. Cellular immune responses persist, humoral responses decrease two decades after recovery from a single source outbreak of hepatitis C. Nat. Med. 6:578-582. 
54. Thimme, R., J. Bukh, H. C. Spangenberg, S. Wieland, J. Pemberton, C Steiger, S. Govindarajan, R. H. Purcell, and F. V. Chisari. 2002. Viral and immunological determinants of hepatitis $\mathrm{C}$ virus clearance, persistence, and disease. Proc. Natl. Acad. Sci. USA 99:15661-15668.

55. Thimme, R., D. Oldach, K. M. Chang, C. Steiger, S. C. Ray, and F. V. Chisari. 2001. Determinants of viral clearance and persistence during acute hepatitis C virus infection. J. Exp. Med. 194:1395-1406.

56. Tomiyama, H., T. Matsuda, and M. Takiguchi. 2002. Differentiation of human $\mathrm{CD}^{+} \mathrm{T}$ cells from a memory to memory/effector phenotype. J. Immunol. 168:5538-5550.

57. Tsai, S.-L., Y.-L. Liaw, M.-H. Chen, C.-Y. Huang, and G. C. Kuo. 1997. Detection of type 2-like T-helper cells in hepatitis $\mathrm{C}$ virus infection: implications for hepatitis $C$ virus chronicity. Hepatology 25:449-458.

58. Varga, S. M., L. K. Selin, and R. M. Welsh. 2001. Independent regulation of lymphocytic choriomeningitis virus-specific $\mathrm{T}$ cell memory pools: relative stability of CD4 memory under conditions of CD8 memory T cell loss. J. Immunol. 166:1554-1561.

59. Vargas, A. L., F. Lechner, M. Kantzanou, R. E. Phillips, and P. Klenerman. 2001. Ex vivo analysis of phenotype and TCR usage in relation to CD45 isoform expression on cytomegalovirus-specific $\mathrm{CD}^{+} \mathrm{T}$ lymphocytes. Clin. Exp. Immunol. 125:432-439.
60. Walker, C. M. 1997. Comparative features of hepatitis $\mathrm{C}$ virus infection in humans and chimpanzees. Springer Semin. Immunopathol. 19:85-98.

61. Weiner, A., A. L. Erickson, J. Kansopon, K. Crawford, E. Muchmore, A. L. Hughes, M. Houghton, and C. M. Walker. 1995. Persistent hepatitis C virus infection in a chimpanzee is associated with emergence of a cytotoxic $\mathrm{T}$ lymphocyte escape variant. Proc. Natl. Acad. Sci. USA 92:2755-2759.

62. Weiner, A. J., X. Paliard, M. J. Selby, A. Medina-Selby, D. Coit, S. Nguyen, J. Kansopon, C. L. Arian, P. Ng, J. Tucker, C. T. Lee, N. K. Polakos, J. Han, S. Wong, H. H. Lu, S. Rosenberg, K. M. Brasky, D. Chien, G. Kuo, and M. Houghton. 2001. Intrahepatic genetic inoculation of hepatitis C virus RNA confers cross-protective immunity. J. Virol. 75:7142-7148.

63. Wills, M. R., A. J. Carmichael, M. P. Weekes, K. Mynard, G. Okecha, R. Hicks, and J. G. Sissons. 1999. Human virus-specific $\mathrm{CD}^{+}$CTL clones revert from CD45ROhigh to CD45RAhigh in vivo: CD45RAhigh $\mathrm{CD}^{+} \mathrm{T}$ cells comprise both naive and memory cells. J. Immunol. 162:7080-7087.

64. Yanagi, M., R. H. Purcell, S. U. Emerson, and J. Bukh. 1997. Transcripts from a single full-length cDNA clone of hepatitis $\mathrm{C}$ virus are infectious when directly transfected into the liver of a chimpanzee. Proc. Natl. Acad. Sci. USA 94:8738-8743.

65. Yanagi, M., M. St. Claire, M. Shapiro, S. U. Emerson, R. H. Purcell, and J. Bukh. 1998. Transcripts of a chimeric cDNA clone of hepatitis C virus genotype $1 \mathrm{~b}$ are infectious in vivo. Virology 244:161-172. 